\title{
Triterpene saponins of Maesa lanceolata leaves
}

\author{
Lawrence Onyango A. Manguro, ${ }^{a^{*}}$ Jacob O. Midiwo, ${ }^{\mathrm{b}}$ Lutz F. Tietze, ${ }^{\mathrm{c}}$ and Pang Hao ${ }^{\mathrm{d}}$
}

${ }^{a}$ Maseno University, Chemistry Department, P. O. Box 333-40105, Maseno, Kenya

${ }^{b}$ University of Nairobi, Chemistry Department, P. O. Box 30197-00100, Nairobi, Kenya

${ }^{c}$ Institute for Organic and Biomolecular Chemistry, Georg-August University Goettingen, Tamannstrasse 2, 37007-Goettingen, Germany

${ }^{d}$ Guangzhou Institute of Geochemistry, Department of Organic Chemistry of Natural Products, Guangzhou, 540640, Guangdong, Peoples Republic of China

E-mail: kamanguro@yahoo.com

\begin{abstract}
Chemical investigation of Maesa lanceolata leaves aqueous $\mathrm{MeOH}$ extract has led to the isolation of eight new triterpene glycosides identified as 16-oxo-28-hydroxyolean-12-ene 3-O$\beta$-glucopyranosyl-(1" $\left.\rightarrow 6^{\prime}\right)$ - $\beta$-glucopyranoside $\quad 1, \quad 16 \alpha, \quad 28$-dihydroxyolean-12-ene 3 $-O-\beta$-[(6"-O-galloylglucopyranosyl-(1" $\left.\left.\rightarrow 2^{\prime}\right)\right]\left[\beta\right.$-glucopyranosyl-(1'"- $\left.\left.\rightarrow 6^{\prime}\right)\right]-\beta$-glucopyranoside $\quad 2$,

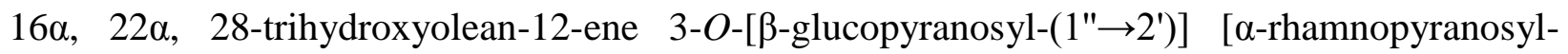
$(1 " ' \rightarrow 6$ ']- $\beta$-glucopyranoside $\quad 3, \quad 22 \alpha$-acetyl-16 $\alpha$-hydroxyolean-12-en-28-al $\quad 3$ - $O$-[ $\alpha$-rhamnopyranosyl$\left(1^{\prime \prime \prime \prime} \rightarrow 66^{\prime \prime}\right)-\beta$-glucopyranosyl- $\left.\left(1^{\prime \prime \prime} \rightarrow 3^{\prime}\right)\right] \quad\left[\beta\right.$-glucopyranosyl- $\left.\left(1^{\prime \prime} \rightarrow 2^{\prime}\right)\right]-\beta$-arabinopyranoside $\quad \mathbf{4}$,

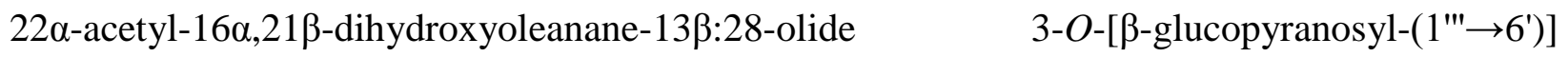
[6"-O-coumaroylglucopyranosyl- $\left.\left(1^{\prime \prime} \rightarrow 2^{\prime}\right)\right]-\beta$-glucopyranoside $\quad \mathbf{5}, \quad 16 \alpha, 22 \alpha$-diacetyl-21 $\beta$ -

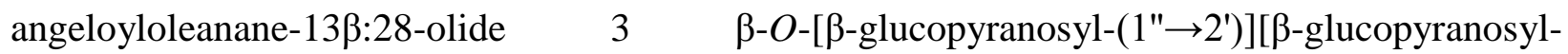
$\left.\left(1^{\prime \prime} \rightarrow 4^{\prime}\right)\right]$ - $\beta$-glucopyranoside $\quad \mathbf{6}, \quad 16 \alpha, 22 \alpha, \quad 28$-trihydroxy $-21 \beta$-angeloyloleanan-12-ene 3 $\beta$ - $O$ - $\left[\alpha\right.$-rhamnopyranosyl- $\left.\left(1{ }^{\prime \prime \prime} \rightarrow 6^{\prime \prime}\right)\right]\left[\beta\right.$-glucopyranosyl $\left.\quad-\left(1 " \rightarrow 2^{\prime}\right)\right]-\beta$-xylopyranoside $\quad 7, \quad 16 \alpha$, 28-dihydroxy-22 $\alpha$-acetyl-21 $\beta$-angeloylolean-12-ene $\quad 3$ - $O$-[ $\beta$-galactopyranosyl-(1" $\left.\rightarrow 2^{\prime}\right)$ ] [ $\alpha$-rhamnopyranosyl- $\left.\left(1^{\prime \prime \prime} \rightarrow 4^{\prime}\right)\right]$ - $\alpha$-arabinopyranoside 8 . Together with these were known compounds quercetin, myricetin, quercetin 3-O-rhamnopyranoside, myricetin

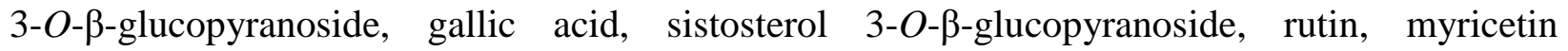
3 - $O$ - $\alpha$-rhamnopyranosyl-( $(1 " \rightarrow 3$ ')- $\beta$-glucopyranoside and quercetin 3,7-O- $\beta$-diglucopyranoside. Their structures were determined using spectroscopic methods as well as comparison with data from known compounds. The in vitro antibacterial activity of aqueous $\mathrm{MeOH}$ extract of the leaves of M. lanceolata was also investigated and zones of inhibition ranging from $28 \pm 0.1$ to $10 \pm 0.2 \mathrm{~mm}$ were observed. The minimum inhibitory concentration (MIC) for the extract ranged between 100 to $1000 \mu \mathrm{g} / \mathrm{ml}$ with the highest activity being observed with Vibro cholerae. Among the pure isolates, compound 6 was the most active and its highest recorded MIC value was $62.5 \mu \mathrm{g} / \mathrm{ml}$ against $V$. cholerae.
\end{abstract}


Keywords: Maesa lanceolata, Myrsinaceae, oleanane saponins, antibacterial activity, leaves

\section{Introduction}

Maesa lanceolata Forsk (Myrsinaceae) is a well known plant used in the Kenyan indigenous system of medicine for the treatment of helminthes and bacterial infections. ${ }^{1}$ In the previous communications, ${ }^{2,3,4,5}$ we reported the isolation of hydroxylated-1, 4-benzoquinone derivatives from the plant various parts. Phytochemical studies undertaken by different group of workers elsewhere on the plant have resulted in the isolation and identification of various acylated triterpene saponins based on oleanane skeleton. ${ }^{6,7,8}$ Recently, flavonol glycosides have been reported from the plant leaves. ${ }^{9}$ The present paper discusses the isolation, structural elucidation and antibacterial activities of triterpene saponins 1-8 from the aqueous methanol extract of the plant leaves.

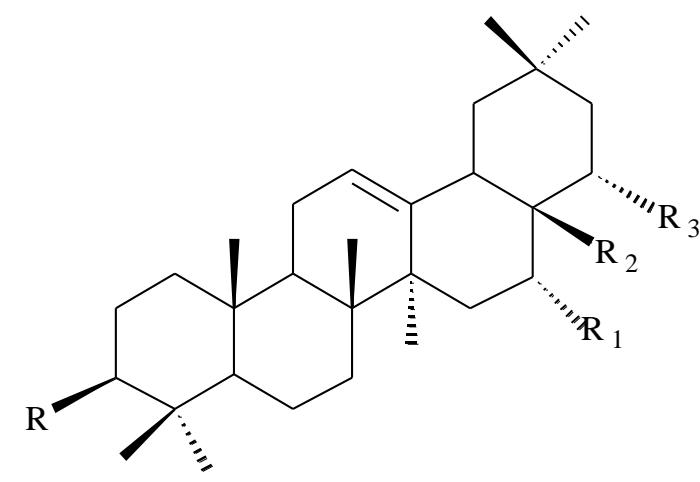

$1 \mathrm{R}=O$-glc- $\left(1^{\prime \prime} \rightarrow 6^{\prime}\right)$-glc, $\mathrm{R}_{1}=\mathrm{O}, \mathrm{R}_{2}=\mathrm{CH}_{2} \mathrm{OH}$,

$\mathrm{R}_{3}=\mathrm{H}$.

$2 \mathrm{R}=O$-[(6"- $O$-galloylglc- $\left.\left(1^{\prime \prime} \rightarrow 2^{\prime}\right)\right]\left[\right.$ glc- $\left.\left(1^{\prime \prime \prime} \rightarrow 6^{\prime}\right)\right]$-glc,

$\mathrm{R}_{1}=\mathrm{OH}, \mathrm{R}_{2}=\mathrm{CH}_{2} \mathrm{OH}, \mathrm{R}_{3}=\mathrm{H}$.

$3 \mathrm{R}=O$-[glc- $\left.\left(1^{\prime \prime} \longrightarrow 2^{\prime}\right)\right]\left[\right.$ rha- $\left.\left(1^{\prime \prime \prime} \rightarrow 6^{\prime}\right)\right]$-glc, $\mathrm{R}_{1}=\mathrm{R}_{3}=\mathrm{OH}$,

$\mathrm{R}_{2}=\mathrm{CH}_{2} \mathrm{OH}$.

$4 \mathrm{R}=O$-[rha- $\left(1^{\prime \prime \prime \prime} \rightarrow 6^{\prime \prime \prime}\right)$-glc- $\left(1^{\prime \prime \prime} \rightarrow 3^{\prime}\right]\left[\right.$ glc- $\left.\left(1^{\prime \prime} \rightarrow 2^{\prime}\right)\right]$-ara,

$\mathrm{R}_{1}=\mathrm{OH}, \mathrm{R}_{2}=\mathrm{CHO}, \mathrm{R}_{3}=\mathrm{OAc}$ 

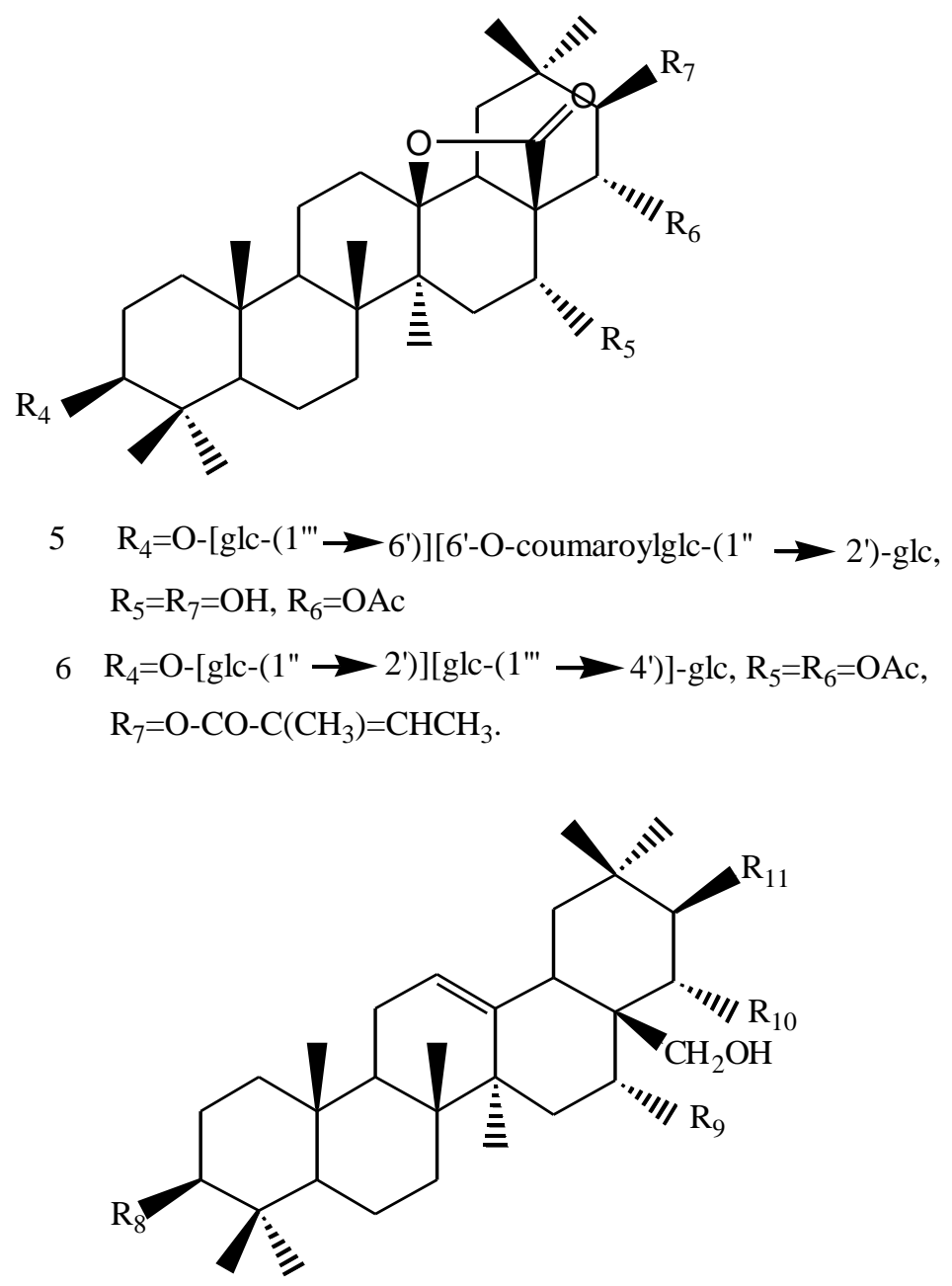

$$
\begin{aligned}
7 \mathrm{R}_{8} & =O-\left[\text { rham- }\left(1^{\prime \prime \prime} \rightarrow 6^{\prime \prime}\right)\right]\left[\text { glc- }\left(1^{\prime \prime} \rightarrow 2^{\prime}\right)\right] \text {-xyl, } \\
\mathrm{R}_{9} & =\mathrm{R}_{10}=\mathrm{OH}, \quad \mathrm{R}_{11}=\mathrm{O}-\mathrm{CO}-\mathrm{C}\left(\mathrm{CH}_{3}\right)=\mathrm{CHCH}_{3} . \\
8 \mathrm{R}_{8} & \left.=O \text {-[gal- }\left(1^{\prime \prime} \rightarrow 2^{\prime}\right)\right]\left[\text { rham- }\left(1^{\prime \prime \prime} \rightarrow 4^{\prime}\right)\right] \text {-ara, } \\
\mathrm{R}_{9} & =\mathrm{OH}, \mathrm{R}_{10}=\mathrm{OAc}, \mathrm{R}_{11}=\mathrm{O}-\mathrm{CO}-\mathrm{C}\left(\mathrm{CH}_{3}\right)=\mathrm{CHCH}_{3}
\end{aligned}
$$

\section{Results and Discussion}

The aqueous $\mathrm{MeOH}$ extract of $M$. lanceolata subjected to column chromatography using sephadex LH-20 and silica gel, and further purification by preparative HPLC afforded triterpene saponins 1-8 together with known compounds 9-17.

Compound 1 analyzed for $\mathrm{C}_{42} \mathrm{H}_{68} \mathrm{O}_{13} \mathrm{Na}$ (HRMS 803.3456, [M+Na] $]^{+}$) was positive to Liebermann-Burchard test and Molish reaction suggesting a triterpene moiety. It exhibited hydroxyl (3430-3150 $\left.\mathrm{cm}^{-1}\right)$, carbonyl $\left(1705 \mathrm{~cm}^{-1}\right)$ and a tri-substituted olefinic bond $\left(1642 \mathrm{~cm}^{-1}\right)$ absorption bands in the IR spectrum. The broad band decoupled ${ }^{13} \mathrm{C}$ and DEPT NMR spectra 
afforded 42 signals accounted for by 7 methyls, 12 methylenes, 15 methines and 8 quartenary carbon atoms. The ${ }^{1} \mathrm{H}$ and ${ }^{13} \mathrm{C}$ NMR data (Tables 1 and 3 ) of compound 1 were closely related to those of schimperinone ${ }^{10,11}$ except for the presence of peaks originating from the sugar units, a fact confirmed by ${ }^{1} \mathrm{H}$ NMR two anomeric proton signals at $\delta 4.70(\mathrm{~d}, J=7.5 \mathrm{~Hz})$ and $4.40(\mathrm{~d}, J=7.6 \mathrm{~Hz})$ with corresponding $\delta_{\mathrm{c}} 103.6$ and 102.8 , respectively in the ${ }^{13} \mathrm{C}$ NMR spectrum. Acid hydrolysis afforded glucose as the sugar residue confirmed by TLC and PC co-chromatography with authentic sample. The large coupling constants of the anomeric protons $(J=7.6 \mathrm{~Hz}$ and $7.5 \mathrm{~Hz})$ indicated that the sugars were present in the $\beta$-configurations. The presence of schimperinone as the aglycone was confirmed by comparing the ${ }^{1} \mathrm{H},{ }^{13} \mathrm{C}$ NMR and MS with the literature data. ${ }^{11}$ Unequivocal information on the ring system and the substitution mode in 1 was established from the ${ }^{1} \mathrm{H},{ }^{13} \mathrm{C}$ NMR and EI-MS data. In the EI-MS spectrum, characteristic peaks at $\mathrm{m} / \mathrm{z} 208$ $\left[\mathrm{C}_{14} \mathrm{H}_{24} \mathrm{O}\right]^{+}(25 \%), 207\left[\mathrm{C}_{14} \mathrm{H}_{23} \mathrm{O}\right]^{+}(21 \%)$ and $248\left[\mathrm{C}_{16} \mathrm{H}_{24} \mathrm{O}_{2}\right]^{+}(11 \%)$ inferred retro-Diels-Alder cleavage of olean-12-ene derivative possessing a hydroxyl group or a sugar unit in rings $\mathrm{A} / \mathrm{B}$ and a keto group together with a terminal oxymethylene in rings $\mathrm{D} / \mathrm{E}$ part of the molecule. ${ }^{11,12,13}$

Analysis of the ${ }^{1} \mathrm{H}$ NMR spectrum revealed the presence of a disaccharide unit at C-3 which was assigned equatorial orientation due to the fact that the geminal proton centred at $\delta 3.50$ appeared as doublet of doublet $(J=11.5$ and $5.0 \mathrm{~Hz})$ and was in axial position. This interpretation was facilitated by the HMBC spectrum which exhibited a cross-peak between glucose-H-1' $(\delta 4.70)$ with $\mathrm{C}-3$ ( $\delta 81.4)$. The protons attached to each signal observed in the ${ }^{13} \mathrm{C}$ spectrum was deduced by analysis of DEPT spectrum and this data, in combination with the ${ }^{1} \mathrm{H}$ NMR spectral data established the oxygenated methylene carbon up field in the ${ }^{13} \mathrm{C}$ NMR at $\delta 70.6$ signifying a terminal $\mathrm{CH}_{2} \mathrm{OH}$ group. ${ }^{14}$ Similarly, the position of hydroxymethylene group was assigned at C-17 on the basis of HMBC cross-peaks between H-28 ( $\delta 3.76)$ and C-16 $(\delta 214.0)$ and between $\mathrm{H}-18(\delta 2.40)$ and $\mathrm{C}-16 / \mathrm{C}-28(\delta$ 70.6).

These results together with fragmentation pattern from EI-MS data confirmed the presence of schimperinone derivative containing a disaccharide at C-3. In the ${ }^{13} \mathrm{C}$ NMR spectrum, one glucose C- 6 was downfield shifted at $\delta 67.3$, suggesting glycosylation of the inner glucose by the terminal one on C-6 hydroxyl, a fact corroborated by HMBC correlation between the glc-C-6' $(\delta 67.3)$ with $\mathrm{H}-1$ " (glc, $\delta 4.40)$. Therefore, based on the above spectroscopic consideration, compound 1 was characterized as schimperinone 3 - $O-\beta$-glucopyranosyl- $\left(1^{\prime \prime} \rightarrow 6^{\prime}\right)$-glucopyranoside (16-oxo-28-hydroxyolean-12-ene-3-O- $\beta$-glucopyranosyl-(1" $\left.\rightarrow 6^{\prime}\right)$ - $\beta$-glucopyranoside).

Compound 2, obtained as an amorphous colorless powder showed the presence of hydroxyl (3460-3100 $\left.\mathrm{cm}^{-1}\right)$, carbonyl $\left(1708 \mathrm{~cm}^{-1}\right)$, double bond $\left(1644 \mathrm{~cm}^{-1}\right)$ and ether linkage $(1050,1020$ $\mathrm{cm}^{-1}$ ) in the IR spectrum. The ${ }^{13} \mathrm{C}$ NMR spectrum revealed 55 carbon signals (Me-x 7, $-\mathrm{CH}_{2}-\mathrm{x}$ 9, $>\mathrm{CH}-\times 6$, $-\mathrm{C}-\times 6,-\mathrm{CH}_{2}-\mathrm{O}-\mathrm{x} 4,>\mathrm{CH}-\mathrm{O}-\mathrm{x} 15,>\mathrm{C}=\mathrm{CH}-\mathrm{x} 1$, aromatic $\mathrm{C}-\mathrm{C}-\mathrm{H} \times 2$, aromatic $\mathrm{C}-\mathrm{C}-\mathrm{OH} \times 3$, $-\mathrm{CO}-\mathrm{O}-\mathrm{x} 1$ and aromatic $>\mathrm{C}=\mathrm{x} 1$ ). The ${ }^{1} \mathrm{H}$ NMR data were similar to those of $3 \beta, 16 \alpha$, 28-trihydroxyolean-12-ene ${ }^{15,16}$ except for the signals due to sugar units $[\delta 4.72(\mathrm{~d}, J=7.7 \mathrm{~Hz}), 4.56$ $(\mathrm{d}, J=7.2 \mathrm{~Hz})$ and $4.42(\mathrm{~d}, J=7.1 \mathrm{~Hz})]$ and the galloyl moiety $[\delta 6.96(\mathrm{~s}, 2 \mathrm{H})] .{ }^{17}$ Acid hydrolysis afforded glucose as the sugar residue identified on the basis of TLC and PC co-chromatography with authentic sample as well as GC analysis. Similarly, the aglycone was identified as 


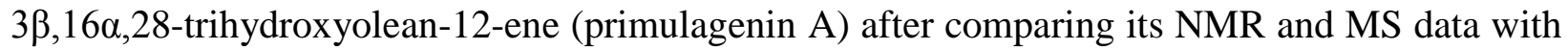
those already reported for the compound. ${ }^{10,11}$ Information on the ring system and the substitution pattern on the aglycone was provided by the EI-MS spectrum which displayed characteristic peaks at $\mathrm{m} / z 207\left[\mathrm{C}_{14} \mathrm{H}_{23} \mathrm{O}\right]^{+}$and $250\left[\mathrm{C}_{16} \mathrm{H}_{26} \mathrm{O}_{2}\right]^{+}$signifying retro-Diels-Alder cleavage typical of olean-12-ene possessing a hydroxyl substituent or sugar moiety in rings $\mathrm{A} / \mathrm{B}$ and two other hydroxyls in rings D/E part of the molecule. ${ }^{10}$ This was further supported by daughter ions at $\mathrm{m} / \mathrm{z}$ $219(22 \%)$ and 201 (41\%) (due to successive loss of $\mathrm{CH}_{2} \mathrm{OH}$ and $\mathrm{H}_{2} \mathrm{O}$ from the $m / z 250$ peak) and $189(100 \%)$. In the ${ }^{1} \mathrm{H}$ NMR spectrum, an oxymethine proton at $\delta 3.50$ (dd, $J=11.6,4.3 \mathrm{~Hz}, \mathrm{H}-3$ ) was coupled to two other protons and from decoupling experiments, it was shown to be part of $-\mathrm{CH}_{2}-\mathrm{CH}-(\mathrm{O}$-glc $)-\mathrm{C}\left(\mathrm{CH}_{3}\right)_{2}-\mathrm{CH}$ - system analogous to the $\mathrm{C}-2$ to $\mathrm{C}-5$ region in oleanane skeleton. ${ }^{18}$ This allowed the oligosaccharide attached to the aglycone to be assigned to $\mathrm{C}-3$ where it is in equatorial configuration, a fact further supported by the HMBC cross-peak between $\mathrm{H}-1$ ' $(\delta 4.72)$ and C-3 ( $\delta$ 80.1), and confirmed by NOESY cross-peaks between H-3 and Me-23 ( $\delta 1.14$ s) and also in turn with H-5.

Similarly, the existence of hydroxyl groups at C-16 and C-28 were deduced from the HMBC correlations between the peaks at $\delta 2.65(\mathrm{dd}, J=14.7,4.5 \mathrm{~Hz}, \mathrm{H}-18)$ and $\mathrm{C}-16(\delta 70.4)$, and between $\mathrm{H}-16(\delta 4.40)$ and C-28 ( $\delta 66.5)$, respectively. The configuration at C-16 was established from NOESY experiments due to spatial proximity observed between $\mathrm{H}-16$ and $\mathrm{H}-15 \beta$. The structure of the sugar chain at C-3 on the aglycone was achieved using 2D-NMR experiments and the results allowed the sequential assignments of all proton resonances within each sugar residue. Similarly, HSQC experiment was used to correlate the protons with corresponding carbons and this allowed the assignment of interglycosidic linkages. In the ${ }^{13} \mathrm{C}$ NMR, glycosylation shifts were observed for C-2' ( $\delta 82.4)$ and C-6' $(\delta$ 68.1) of the inner glucose, thus suggesting that the terminal glucose moieties were linked to primary glucose through $1 " \rightarrow 2^{\prime}$ and $1 " ' \rightarrow 6$ " bonds, respectively. The foregoing evidence was confirmed by HMBC correlations between the glucose-H-1"' $(\delta 4.42)$ and the glucose-C-6' $(\delta 68.1)$ and between the glucose-H-1" ( $\delta 4.56)$ with glucose-C-2'. Similarly, the long range correlation between glucose- $\mathrm{CH}_{2}-6$ " ( $\delta 4.14$ and 3.87) with the galloyl-C-7 ( $\delta$ 168.1) allowed the localization of the galloyl residue on the second glucose-C-6".

Thus, on the basis of spectroscopic data, compound 2 was concluded to be $16 \alpha$, 28 -dihydroxyolean-12-ene $\quad 3-O-\beta-\left[\left(6^{\prime \prime}-O\right.\right.$-galloylglucopyranosyl-(1" $\left.\left.\rightarrow 2^{\prime}\right)\right][\beta$-glucopyranosyl$\left.\left(1^{\prime \prime \prime} \rightarrow 6^{\prime}\right)\right]-\beta$-glucopyranoside.

Compound $\mathbf{3}$, isolated as colorless amorphous powder showed a sodiated molecular ion peak at $m / z 967.4562[\mathrm{M}+\mathrm{Na}]^{+}$in the positive electron spray ionization-MS corresponding to $\mathrm{C}_{48} \mathrm{H}_{80} \mathrm{O}_{18}$ $\mathrm{Na}$ formula. The ${ }^{1} \mathrm{H}$ NMR spectrum revealed the presence of seven tertiary methyl groups $(\delta 0.86$, $0.88,0.92,0.96,1.00,1.15$, and 1.35$)$, one trisubstituted olefinic proton $(\delta 5.31)$, three oxymethine protons $(\delta 3.56,4.21,4.30)$, terminal hydroxymethylene $(\delta 4.10,3.81)$ and three anomeric protons [ $84.80(\mathrm{~d}, J=7.7 \mathrm{~Hz}), 4.60(\mathrm{~d}, J=7.4 \mathrm{~Hz})$ and $4.50(\mathrm{~d}, J=1.1 \mathrm{~Hz})]$. The ${ }^{13} \mathrm{C}$ NMR spectrum (Table 3$)$ showed signals for a pair of olefinic carbons ( $\delta 123.5$ and 144.6) and three anomeric carbons $(\delta$ $102.1,101.3$ and 100.8). On acid hydrolysis, glucose and rhamnose were identified as the sugar residues by TLC and PC co-chromatography with authentic sample and GC analysis. Similarly, the 
aglycone, 16 $2,22 \alpha$, 28-trihydroxy -12-oleanene was suggested after comparison of its spectroscopic data $\left({ }^{1} \mathrm{H},{ }^{13} \mathrm{C}\right.$ and MS) with those already reported. ${ }^{19}$ The relative stereochemistry of the substituents on the aglycone was determined by NOESY experiments. The configuration of $\mathrm{H}-3$ was assigned as $\alpha$ on the basis of correlations between $\mathrm{H}-3 / \mathrm{H}-5$ and $\mathrm{Me}-23$, and the inter-proton coupling constant $(\delta 3.56$, dd, $\mathrm{J}=11.5,4.2 \mathrm{~Hz}$ ). Cross-peak observed between H-18 and $\mathrm{H}-22$ indicated close spatial proximity between the two protons. The other significant NOESY correlation was observed between $\mathrm{H}-15 \beta / \mathrm{H}-16$. These NOESY results are consistent with the structure in which the hydroxyls at C-16 and C-22 are both $\alpha$-oriented and the $\mathrm{C}-3$ substituent has $\beta$-configuration. ${ }^{20}$ The spin systems for the sugars were assigned on the basis of spectroscopic evidences obtained from ${ }^{1} \mathrm{H}-{ }^{1} \mathrm{H}$ COSY and HSQC while the inter-glycosidic linkages were evaluated using ${ }^{13} \mathrm{C}$ NMR and HMBC experiments. In the HMBC spectrum, long-range couplings $\left({ }^{3} \mathrm{~J}_{\mathrm{HOH}}\right)$ were observed between proton signals at $\delta 4.60$ (glc-H-1") and 4.50 (rha-H-1'") with carbon resonances at $\delta 81.1$ (C-2') and $\delta 67.9$ (glc-C-6'), respectively, thus suggesting the presence of 2',6'-disubstituted glucose bearing another glucose and rhamnose as terminal sugars. The signal at $\delta 81.1$ attributable to C-2' of primary glucose indicated glucopyranosyl $(1 \rightarrow 2)$-glucopyranosyl arrangement (as in sophorosyl) while that at $\delta 67.9$ attributed to C-6' of the same glucose signified rhamnopyranosyl-( $1 \rightarrow 6)$-glucopyranosyl moiety (as in rutinosyl). ${ }^{21}$

The ${ }^{13} \mathrm{C}$ NMR data for the trisaccharide were in agreement with $\left[\alpha\right.$-rhamnopyranosyl- $\left.\left(1^{\prime \prime \prime} \rightarrow 6^{\prime}\right)\right]\left[\beta\right.$-glucopyranosyl- $\left.\left(1^{\prime \prime} \rightarrow 2^{\prime}\right)\right]$-glucopyranosyl moiety. ${ }^{21,22}$ Thus, based on the above spectroscopic evidences, compound $\mathbf{3}$ was deduced to be $16 \alpha, 22 \alpha, 28$-trihydroxyolean-12-ene-3- $O$-[ $\left[\beta\right.$-glucopyranosyl-( $\left.\left(1^{\prime \prime} \rightarrow 2^{\prime}\right)\right][\alpha$-rhamnopyranosyl $\left.-\left(1^{\prime \prime \prime} \rightarrow 6 '\right)\right]-\beta$-glucopyranoside.

Compound 4 was obtained as a colorless amorphous powder from aqueous MeOH. Its ESI-MS quasimolecular ion peak at $\mathrm{m} / z$ 1117.3425 $[\mathrm{M}+\mathrm{H}]^{+}$and the ${ }^{13} \mathrm{C}$ NMR data in combination with distortionless enhancement by polarization transfer (DEPT $45^{\circ}, 90^{\circ}$ and $135^{\circ}$ ) suggested a molecular formula of $\mathrm{C}_{55} \mathrm{H}_{88} \mathrm{O}_{23}$. The IR spectrum showed significant absorption peaks for hydroxyl $\left(3450 \mathrm{~cm}^{-1}\right)$, ester carbonyl $\left(1736 \mathrm{~cm}^{-1}\right)$, aldehyde $\left(1711 \mathrm{~cm}^{-1}\right)$ and double bond $(1650$ $\mathrm{cm}^{-1}$ ) groups. The ${ }^{13} \mathrm{C}$ NMR spectrum (Table 3) exhibited 55 carbons of which 30 were assigned to the aglycone part, two to the acetyl group and 23 to the saccharide moiety. The seven $\mathrm{sp}^{3}$ tertiary carbon signals at $\delta 30.9,28.6,26.6,19.9,17.2,16.5,15.4$ and the three $\mathrm{sp}^{2}$ hybridized carbons at $\delta$ 203.3, 144.3 and 124.8, together with the information from ${ }^{1} \mathrm{H}$ NMR (seven methyl proton singlets and a broad triplet vinyl proton at $\delta$ 5.36), suggested that the aglycone possessed an olean-12-ene skeleton with an aldehyde group. ${ }^{19}$ The combined interpretation of ${ }^{1} \mathrm{H}$ and ${ }^{13} \mathrm{C}$ NMR aided by HSQC allowed association of most protons with the corresponding carbon signals, and by the HMBC spectrum, which was vital in connecting the various spin systems, the aglycone was suggested to be $3 \beta, 22 \alpha$-dihydroxyolean -12-en-28-al, a fact corroborated by the EIMS peaks at $m / z$ 514.2. ${ }^{19}$ The position of the oligosaccharide unit on the aglycone was established from HMBC experiments to be attached glycosidically at C-3 and from spin decoupling experiment it was in $\beta$-configuration. ${ }^{18}$ The presence of key HMBC correlations between H-16 ( $\left.\delta 4.34\right) / \mathrm{H}-18(\delta 2.56)$ and C-22 ( $\delta 74.4)$; between H-16/H-18/ H-22 ( $\delta$ 5.21) and C-28 ( $\delta 203.3)$, and between H-22 and 
the acetyl group $(\delta$ 170.2) unambiguously confirmed the disposition of hydroxyl, acetyl and aldehyde groups at C-16, C-22 and C-28, respectively on the aglycone, a fact further confirmed by NOESY plot (Fig. 1). Acid hydrolysis yielded glucose, rhamnose and arabinose as the sugar residues identified by TLC and PC co-chromatography after comparison with authentic sugar samples and also by GC-analysis. This was further corroborated by the ${ }^{1} \mathrm{H}$ NMR spectrum which displayed four anomeric proton signals at $4.77(\mathrm{~d}, J=4.7 \mathrm{~Hz}), 4.61(\mathrm{~d}, J=7.6 \mathrm{~Hz}), 4.58(\mathrm{~d}, J=1.2 \mathrm{~Hz})$ and $4.46(\mathrm{~d}, J=7.4 \mathrm{~Hz})$ with corresponding $\delta 104.2,102.1,101.1$ and 100.7 , respectively in the ${ }^{13} \mathrm{C}$ NMR spectrum. The information about the sequence of oligosaccharide chain was provided by ESI-MS, ${ }^{13} \mathrm{C}$ NMR and HMBC correlations. In the ESI-MS, an ion at $m / z 1117.4\left(\mathrm{C}_{55} \mathrm{H}_{88} \mathrm{O}_{23} \mathrm{H}\right)$ together with other significant daughter ions at $\mathrm{m} / \mathrm{z}$ 971.1 [M+H-146] ${ }^{+}$(loss of rhamnose), 809.5 $[\mathrm{M}+\mathrm{H}-162-146]^{+}$(loss of glucose and rhamnose), $647.0[\mathrm{M}+\mathrm{H}-2 \mathrm{x} 162-146]^{+}$(loss of two glucose and rhamnose), $515.2[\mathrm{M}+\mathrm{H}-2 \times 162-146-132]^{+}$(loss of two glucose, arabinose and rhamnose) and $455.3\left[\mathrm{M}+\mathrm{H}-2 \times 162-146-132-\mathrm{CH}_{3} \mathrm{COOH}\right]^{+}$(loss of 2 glucose, arabinose, rhamnose and acetic acid) confirmed that the compound is a triterpene tetraglycoside possibly with rhamnose and glucose as terminal sugars. In an effort to obtain a specific sequence on the carbohydrate moiety, fragmentations observed at $\mathrm{m} / \mathrm{z} \quad 603.1 \quad$ [arabinopyranosyl-glucopyranosyl -glucopyranosyl-rhamnopyranosyl] ${ }^{+}, 458.3$ [arabinopyranosyl-glucopryanosyl-glucopyranosyl] ${ }^{+}$, 441.1 [arabinopyranosyl-glucopyranosyl-rhamnopyranosyl] ${ }^{+} \quad 309.1 \quad$ [glucopyranosyl -rhamnopyranosyl] ${ }^{+}, 295.0$ [arabinopyranosyl-glucopyranosyl] ${ }^{+}$, were consistent with arabinose moiety containing two glucose and a rhamnose units. The formation of these fragment ions as outlined in Fig. 2 showed that arabinose moiety was the innermost sugar unit while one glucose and rhamnose were present as terminal ones.

From the mass spectral data, the sequence [(rhamnopyranosyl-glucopyranosyl)] [(glucopyranosyl-arabinopyranosyl-glucopyranosyl)]-aglycone could be unambiguously established and support for this was shown by ${ }^{1} \mathrm{H}$ and ${ }^{13} \mathrm{C}$ NMR, DEPT, ${ }^{1} \mathrm{H}-{ }^{1} \mathrm{H}$ COSY, ${ }^{1} \mathrm{H}-{ }^{13} \mathrm{C}$ heteronuclear HSQC and HMBC. In the HMBC, the ${ }^{13} \mathrm{C}$ NMR glucose carbon signal at $\delta 102.1$ (C-1") showed correlation with ${ }^{1} \mathrm{H}$ NMR peak at $\delta 3.51$, which was assignable to arabinose-H-2'. Similarly, the multiplet $\mathrm{H}-2^{\prime}$ directly correlated with the ${ }^{13} \mathrm{C}$ NMR signal at $\delta 81.4\left(\mathrm{C}-2^{\prime}\right)$ in the HSQC spectrum and with $\delta 82.5$ (C-3') in the HMBC. It was also observed that in the HMBC spectrum, the arabinose-H-3' $(\delta$ 3.43) showed a long range correlation with the other glucose anomeric carbon peak at $\delta 101.1$ (C-1"'). The latter signal directly correlated with a ${ }^{1} \mathrm{H}$ NMR signal at $\delta 4.46(\mathrm{~d}, J=7.4 \mathrm{~Hz})$, thus these signals were attributed to $\mathrm{C}-1$ "' and $\mathrm{H}-1{ }^{\prime \prime}$ of the glucose II, respectively. The terminal rhamnose unit was linked to glucose II through 1 "'" $\rightarrow 6$ "' bond as evidenced by downfield peak at $\delta 68.1$, a fact that was supported by long-range correlation of H-1"'" $(\delta 4.58, J=1.2 \mathrm{~Hz})$ with C-6"' $(\delta 68.1)$. The latter peak in turn correlated with the multiplet H-5"' ( $\delta 3.24)$. Thus, the glycosidic linkage sites were in agreement with the mass spectral results. Hence, sequence of saccharide moiety was evaluated as

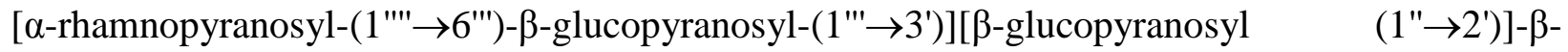
arabinopyranoside. Therefore on the basis of spectroscopic evidence, compound 4 was structurally elucidated as 22 $\alpha$-acetyl-16 $\alpha$-hydroxyolean-12-en-28-al $\quad 3$ - $O$-[ $\alpha$-rhamnopyranosyl- 


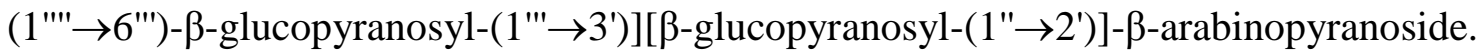
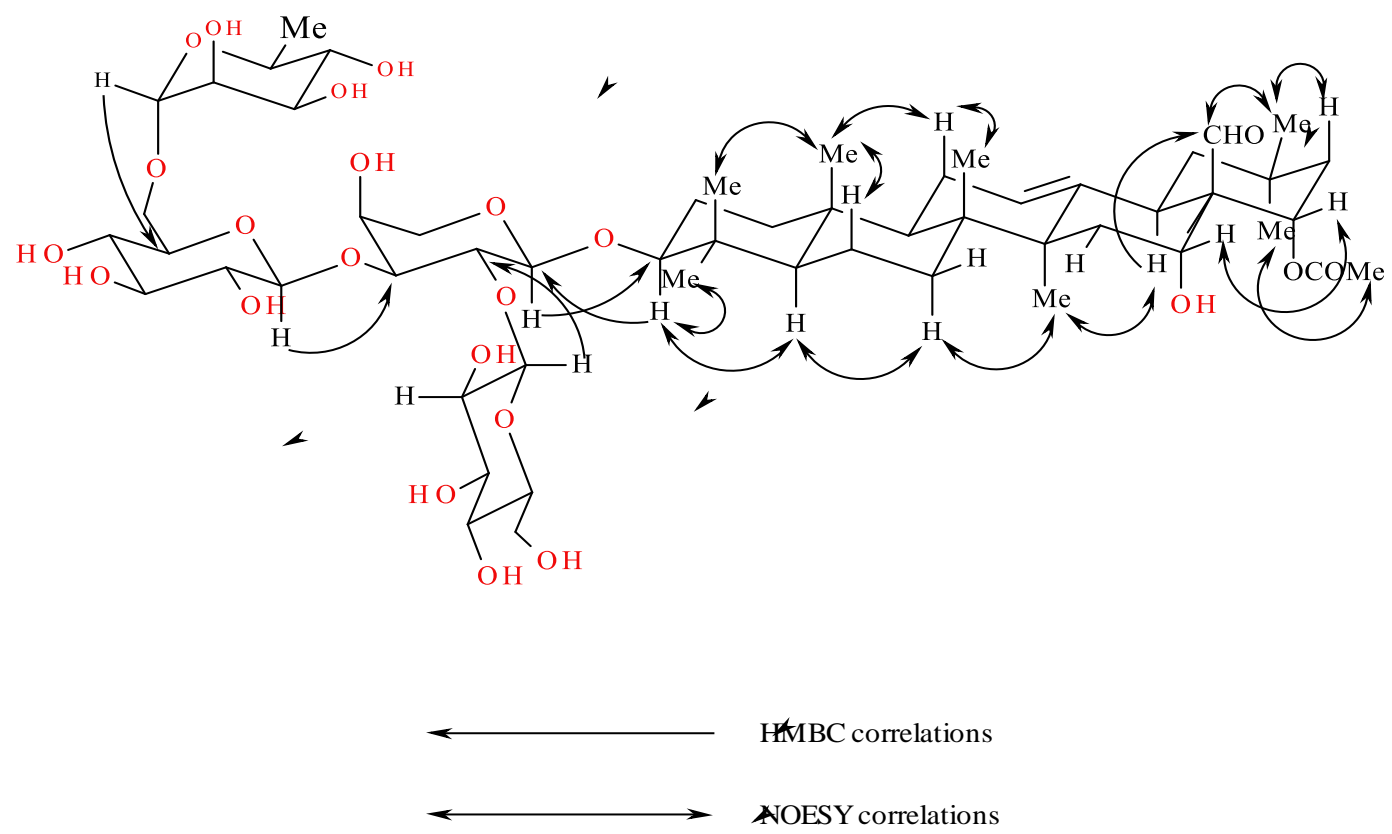

Figure 1. Significant HMBC and NOESY correlations of compound 4.

Compound $\mathbf{5}$, isolated as amorphous powder by repeated column chromatography followed by reverse-phase preparative HPLC afforded an ESI-MS molecular ion at $m / z, 1201.5483[\mathrm{M}+\mathrm{Na}]^{+}$ corresponding to $\mathrm{C}_{59} \mathrm{H}_{86} \mathrm{O}_{24}$ formula. The ${ }^{1} \mathrm{H}$ and ${ }^{13} \mathrm{C}$ NMR spectra (Tables 1 and 3) corroborated the finding and in addition, revealed the presence of a triglycosidic chain containing a coumaroyl moiety [evidenced by ${ }^{1} \mathrm{H}$ NMR peaks $\delta 7.40$ (d, $J=8.6 \mathrm{~Hz}, \mathrm{H}-9$ and H-5), 7.25 (d, $J=15.9 \mathrm{~Hz}, \mathrm{H}-3$ ), $6.95(\mathrm{~d}, J=8.8 \mathrm{~Hz}, \mathrm{H}-6$ and H-8) and $6.20(\mathrm{~d}, J=15.9 \mathrm{~Hz}, \mathrm{H}-2)] .{ }^{23}$ Like in compound 4, the combined interpretation of the spectral data was aided by the HSQC and HMBC spectra. In the ${ }^{1} \mathrm{H}$ NMR spectrum the four carbinylic protons [ $\delta 4.40$ (br s H-16), 4.96 (d, J=10.8 Hz, H-22), 4.50 (d, $J=11.0 \mathrm{~Hz}, \mathrm{H}-21)$ and $3.60(\mathrm{dd}, J=11.2,3.8 \mathrm{~Hz}, \mathrm{H}-3)$ and the seven tertiary methyl singlets $(\delta 1.30$, $1.21,1.01,0.93,0.89,0.87$ and 0.86$)$ in combination with the ${ }^{13} \mathrm{C}$ NMR peaks at $\delta 180.4(\mathrm{C}-28)$ and $92.6(\mathrm{C}-13)$ suggested that the aglycone is an oleanane derived triterpenoid $\left(\mathrm{C}_{30}\right)$ skeleton with oxygen functionalities in positions C-3, C-16, C-21 and C-22 in addition to the epoxy- $\gamma$-lactone moiety at $\mathrm{C}-13$ and $\mathrm{C}-28 .{ }^{18}$ The presence of the latter functionality was further supported by IR spectrum characteristic peaks at 1758 and $875 \mathrm{~cm}^{-1} \cdot{ }^{24,25,26}$ The downfield shift of the ${ }^{1} \mathrm{H}$ NMR signal at $\delta 4.96$ suggested the presence of an acetyl group and was confirmed by HMBC cross-peak between the H-22 ( $\delta$ 4.96) and $\delta 171.0$ (acetyl group) to be at C-22. The relative stereochemistry of the saponin molecule, particularly at positions C-3, C-16, C-21 and C-22 was deduced from NOESY spectrum, whereby H-22 was observed to correlate with Me-30, indicating the $\alpha$-configuration of the acetyl group. Also, in the ${ }^{1} \mathrm{H}$ NMR spectrum, H-21 and H-22 peaks 
inferred an $\mathrm{AB}$ system typical of two vicinal oxygenated methine carbons having a trans-stereochemistry. ${ }^{6,7}$ The two proton signals were observed to correlate strongly in the ${ }^{1} \mathrm{H}-{ }^{1} \mathrm{H}$ COSY spectrum, thus suggesting the $\beta$-configuration of the hydroxyl group at $\mathrm{C}-21$ and was further supported by NOESY cross-peak between H-21 and Me-29. The $\alpha$-configuration of the C-16 substituent was evident from the NOESY correlation between H-16 and H-15 $\beta$. Similarly, the ${ }^{13} \mathrm{C}$ NMR signal at $\delta 83.1$ indicating a glycosidation shift was in addition to the earlier mentioned $\mathrm{HMBC}$ evidence for compound $\mathbf{5}$, which is suggestive of the $\mathrm{C}-3$ linkage to the sugar moiety. H-3 correlated with Me-23 and H-5 of the aglycone nucleus in the NOESY spectrum indicating a $\beta$-configuration of the $\mathrm{C}-3$ oligosaccharide group.

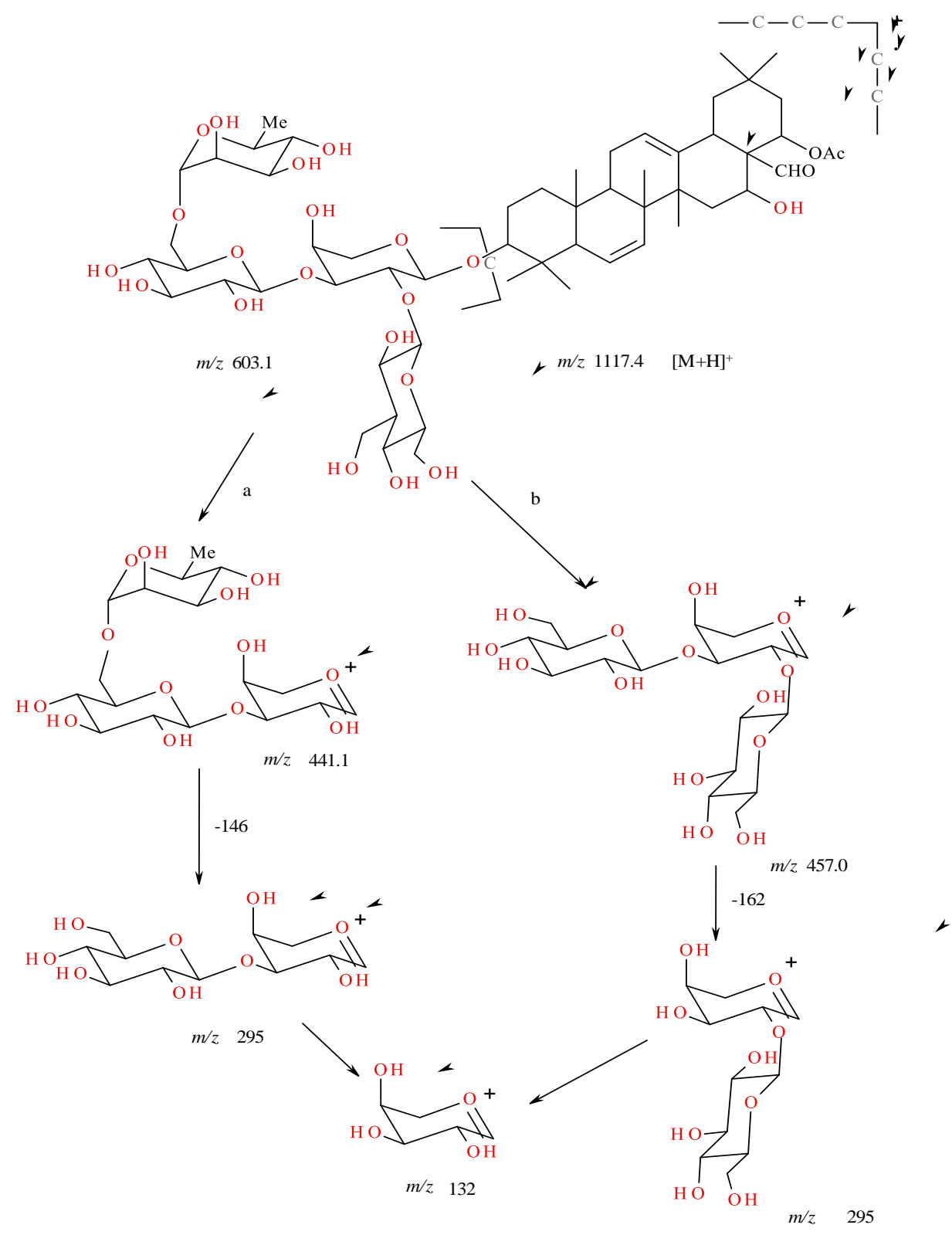

Figure 2. Fragmentation of 4 in ESIMS. 
Acid hydrolysis of compound $\mathbf{5}$ afforded glucose as the sugar residue similarly identified as those for compound 4. The sequence of the sugar chain at $\mathrm{C}-3$ on the aglycone was achieved by ${ }^{1} \mathrm{H}$ and ${ }^{13} \mathrm{C}$ NMR, ${ }^{1} \mathrm{H}-{ }^{1} \mathrm{H}$ COSY, HSQC and HMBC experiments. The sugar-sugar and the sugar-coumaroyl linkages were assigned using ${ }^{13} \mathrm{C}$ NMR spectrum on the basis of the downfield shift of the inner glucose-C-2' and C-6' to $\delta 82.0$ and 67.5 , respectively, ${ }^{25}$ confirmed by the HMBC cross-peaks between glucose-H-1" $(\delta$ 4.41) and glucose-C-2' $(\delta$ 82.0), between glucose-H-1"' $(\delta$ 4.92) and glucose-C-6' ( $\delta$ 67.5). On the other hand, the appearance of a third glucose-C-6" downfield at $\delta 68.5$ pointed out that the coumaroyl moiety was at this position and was confirmed by HMBC cross-peaks between glucose- $\mathrm{CH}_{2}-6$ " $(\delta 4.30,3.91)$ and coumaroyl-C-1 ( $\left.\delta 167.0\right)$. On

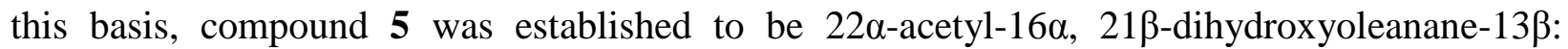

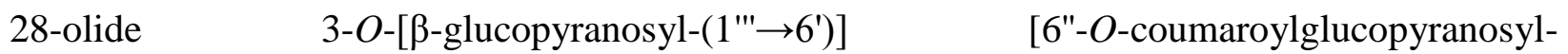
$(1 " \rightarrow 2 ')]$ - $\beta$-glucopyranoside.

Table 1. ${ }^{1} \mathrm{H}$ NMR of compounds 1-5

\begin{tabular}{|c|c|c|c|c|c|}
\hline C & 1 & 2 & 3 & 4 & 5 \\
\hline 1 & $1.88 \mathrm{~m}, 1.30 \mathrm{~m}$ & $1.61 \mathrm{~m}, 1.10 \mathrm{~m}$ & $1.70 \mathrm{~m}, 1.11 \mathrm{~m}$ & $1.66 \mathrm{~m}, 1.00 \mathrm{~m}$ & $1.73 \mathrm{~m}, 0.88 \mathrm{~m}$ \\
\hline 2 & $2.36 \mathrm{~m}, 2.18 \mathrm{~m}$ & $1.86 \mathrm{~m}, 1.46 \mathrm{~m}$ & $2.00 \mathrm{~m}, 1.60 \mathrm{~m}$ & $1.94 \mathrm{~m}, 1.86 \mathrm{~m}$ & $1.92 \mathrm{~m}, 1.84 \mathrm{~m}$ \\
\hline 3 & $\begin{array}{c}3.50 \mathrm{dd}(11.5 \\
5.0)\end{array}$ & $\begin{array}{c}3.50 \mathrm{dd}(11.6 \\
4.3)\end{array}$ & $\begin{array}{c}3.56 \mathrm{dd}(11.5 \\
4.2)\end{array}$ & $\begin{array}{c}3.58 \mathrm{dd}(10.8 \\
5.0)\end{array}$ & $\begin{array}{c}3.60 \mathrm{dd}(11.2 \\
3.8)\end{array}$ \\
\hline \multicolumn{6}{|l|}{4} \\
\hline 5 & $0.81 \mathrm{~m}$ & $1.02 \mathrm{~d}(11.7)$ & $0.87 \mathrm{~m}$ & $\begin{array}{c}0.86 \mathrm{dd}(11.2 \\
1.8)\end{array}$ & $\begin{array}{c}0.85 \mathrm{~d}(11.0 \\
1.8)\end{array}$ \\
\hline 6 & $1.51 \mathrm{~m}, 1.30 \mathrm{~m}$ & $1.56 \mathrm{~m}, 1.33 \mathrm{~m}$ & $1.36 \mathrm{~m}, 1.57 \mathrm{~m}$ & $1.48 \mathrm{~m}, 1.28 \mathrm{~m}$ & $1.44 \mathrm{~m}, 1.27 \mathrm{~m}$ \\
\hline 7 & $1.63 \mathrm{~m}, 1.28 \mathrm{~m}$ & $1.69 \mathrm{~m}, 1.26 \mathrm{~m}$ & $1.63 \mathrm{~m}, 1.34 \mathrm{~m}$ & $1.56 \mathrm{~m}, 1.24 \mathrm{~m}$ & $1.66 \mathrm{~m}, 1.26 \mathrm{~m}$ \\
\hline \multicolumn{6}{|l|}{8} \\
\hline 9 & $1.61 \mathrm{~m}$ & $1.64 \mathrm{~m}$ & $1.53 \mathrm{~m}$ & $1.54 \mathrm{~m}$ & $1.35 \mathrm{~m}, 1.04 \mathrm{~m}$ \\
\hline \multicolumn{6}{|l|}{10} \\
\hline 11 & $1.93 \mathrm{~m}, 1.84 \mathrm{~m}$ & $1.98 \mathrm{~m}, 1.88 \mathrm{~m}$ & $1.95 \mathrm{~m}, 1.91 \mathrm{~m}$ & $\begin{array}{l}1.90 \mathrm{dd}(8.5, \\
4.1), 1.64 \mathrm{~m}\end{array}$ & $1.86 \mathrm{~m}, 1.43 \mathrm{~m}$ \\
\hline 12 & $5.34 \mathrm{t}(4.3)$ & $5.32 \mathrm{t}(4.1)$ & $5.31 \mathrm{t}(4.0)$ & $5.36 \mathrm{t}(3.8)$ & $\begin{array}{c}1.98 \text { dd }(13.6, \\
4.8)\end{array}$ \\
\hline & & & & & $\begin{array}{c}1.62 \mathrm{dd}(14.5, \\
3.4)\end{array}$ \\
\hline \multicolumn{6}{|l|}{13} \\
\hline \multicolumn{6}{|l|}{14} \\
\hline 15 & $1.89 \mathrm{~m}, 1.47 \mathrm{~m}$ & $1.77 \mathrm{~m}, 1.45 \mathrm{~m}$ & $1.76 \mathrm{~m}, 1.43 \mathrm{~m}$ & $\begin{array}{c}1.83 \mathrm{dd}(15.4 \\
5.6), 1.48 \mathrm{dd} \\
(15.6,2.8)\end{array}$ & $\begin{array}{c}1.96 \mathrm{dd}(15.0 \\
4.8), 1.62 \mathrm{~m}\end{array}$ \\
\hline 16 & & 4.40 br s & 4.30 br s & 4.34 br s & 4.40 br s \\
\hline 17 & & & & & \\
\hline
\end{tabular}


$18 \quad 2.40 \mathrm{dd}(15.2, \quad 2.65 \mathrm{dd}(14.7, \quad 2.73 \mathrm{dd}(14.8, \quad 2.56 \mathrm{dd}(14.4, \quad 2.01 \mathrm{dd}(13.6$, $\begin{array}{lllll}4.1) & 4.5) & 3.6) & 4.0) & 3.8)\end{array}$

$19 \quad 2.30 \mathrm{~m}, 1.35 \mathrm{~m} \quad 2.21 \mathrm{~m}, 1.10 \mathrm{~m} \quad 2.27 \mathrm{~m}, 1.15 \mathrm{~m} \quad 2.32 \mathrm{~m}, 1.25 \mathrm{~m} \quad 2.56 \mathrm{~m}, 1.33 \mathrm{~m}$ 20

$21 \quad 2.14 \mathrm{~m}, 1.57 \mathrm{~m} \quad 1.91 \mathrm{~m}, 1.20 \mathrm{~m} \quad 2.06 \mathrm{~m}, 1.61 \mathrm{~m} \quad 1.85 \mathrm{dd}(11.7, \quad 4.50 \mathrm{~d}(11.0)$

$\begin{array}{lccccc}22 & & & & 11.5) & \\ 23 & 1.10 \mathrm{~m} & 1.93 \mathrm{~m}, 1.71 \mathrm{~m} & 4.21 \mathrm{~m} & 5.21 \mathrm{~m} & 4.96 \mathrm{~d}(10.8) \\ 24 & 1.16 \mathrm{~s} & 1.14 \mathrm{~s} & 1.15 \mathrm{~m} & 1.11 \mathrm{~s} & 1.21 \mathrm{~s} \\ 25 & 0.89 \mathrm{~s} & 0.92 \mathrm{~s} & 0.86 \mathrm{~s} & 0.91 \mathrm{~s} & 0.89 \mathrm{~s} \\ 26 & 0.95 \mathrm{~s} & 0.98 \mathrm{~s} & 0.96 \mathrm{~s} & 0.95 \mathrm{~s} & 1.01 \mathrm{~s} \\ 27 & 0.90 \mathrm{~s} & 0.88 \mathrm{~s} & 0.88 \mathrm{~s} & 0.84 \mathrm{~s} & 0.86 \mathrm{~s} \\ 28 & 1.28 \mathrm{~s} & 1.30 \mathrm{~s} & 1.35 \mathrm{~s} & 1.36 \mathrm{~s} & 1.30 \mathrm{~s} \\ & 3.76 \mathrm{~d}(10.4), & 3.90 \mathrm{~d}(11.0), & 4.10 \mathrm{~d}(9.6), & 9.60 \mathrm{~s} & \\ 29 & 0.57 \mathrm{~d}(10.4) & 3.80 \mathrm{~d}(11.0) & 3.81 \mathrm{~d}(9.6) & & \\ 30 & 0.96 \mathrm{~s} & 0.87 \mathrm{~s} & 0.92 \mathrm{~s} & 0.87 \mathrm{~s} & 0.87 \mathrm{~s} \\ & & 1.02 \mathrm{~m} & 1.00 \mathrm{~s} & 1.00 \mathrm{~s} & 0.93 \mathrm{~s}\end{array}$

\begin{tabular}{|c|c|c|c|c|}
\hline $4.70 \mathrm{~d}(7.5)$ & $4.72 \mathrm{~d}(7.7)$ & $4.80 \mathrm{~d}(7.7)$ & $4.77 \mathrm{~d}(4.7)$ & $4.85(7.6)$ \\
\hline $3.31 \mathrm{t}(8.5)$ & $3.95 \mathrm{t}(8.3)$ & $3.30 \mathrm{~m}$ & $3.51 \mathrm{~m}$ & $3.63 \mathrm{~m}$ \\
\hline $3.39 \mathrm{~m}$ & $3.51 \mathrm{~m}$ & $3.44 \mathrm{~m}$ & $3.43 \mathrm{~m}$ & $3.56 \mathrm{t}(8.7)$ \\
\hline $3.32 \mathrm{~m}$ & $3.34 \mathrm{t}(9.5)$ & $3.38 \mathrm{~m}$ & $3.33 \mathrm{~m}$ & $3.44 \mathrm{~m}$ \\
\hline $3.52 \mathrm{~m}$ & $\begin{array}{c}3.55 \text { ddd }(9.5 \\
5.5,5.3)\end{array}$ & $3.53 \mathrm{~m}$ & $3.46 \mathrm{~m}$ & $3.48 \mathrm{~m}$ \\
\hline $3.98 \mathrm{~m}, 3.73 \mathrm{~m}$ & $4.01 \mathrm{~m}, 3.90 \mathrm{~m}$ & $3.82 \mathrm{~m}, 3.66 \mathrm{~m}$ & $4.01 \mathrm{~m}$ & $3.86 \mathrm{~m}, 3.66 \mathrm{~m}$ \\
\hline $4.40 \mathrm{~d}(7.6)$ & $4.56 \mathrm{~d}(7.2)$ & $4.60 \mathrm{~d}(7.4)$ & $4.61 \mathrm{~d}(7.6)$ & $4.41 \mathrm{~d}(7.1)$ \\
\hline $3.29 \mathrm{t}(8.6)$ & $3.48 \mathrm{~m}$ & $3.33 \mathrm{~m}$ & $3.37 \mathrm{~m}$ & $3.38 \mathrm{~m}$ \\
\hline $3.37 \mathrm{~m}$ & $3.38 \mathrm{~m}$ & $3.46 \mathrm{~m}$ & $3.31 \mathrm{~m}$ & $3.49 \mathrm{~m}$ \\
\hline $3.26 \mathrm{~m}$ & $3.66 \mathrm{~m}$ & $3.36 \mathrm{~m}$ & $3.34 \mathrm{~m}$ & $3.41 \mathrm{~m}$ \\
\hline $3.46 \mathrm{~m}$ & $3.57 \mathrm{~m}$ & $3.28 \mathrm{~m}$ & $3.29 \mathrm{~m}$ & $3.36 \mathrm{~m}$ \\
\hline $3.68 \mathrm{~m}, 3.52 \mathrm{~m}$ & $\begin{array}{c}4.11 \mathrm{~m}, 3.87 \mathrm{~m} \\
4.42 \mathrm{~d}(7.1)\end{array}$ & $\begin{array}{c}3.76 \mathrm{~m}, 3.59 \mathrm{~m} \\
4.50 \mathrm{~d}(1.1)\end{array}$ & $\begin{array}{c}3.84 \mathrm{~m}, 3.70 \mathrm{~m} \\
4.46 \mathrm{~d}(7.4)\end{array}$ & $\begin{array}{c}4.30 \mathrm{~m}, 3.91 \mathrm{~m} \\
4.92 \mathrm{~d}(7.3)\end{array}$ \\
\hline 2"' & $3.74 \mathrm{~m}$ & $3.80 \mathrm{~m}$ & $3.40 \mathrm{~m}$ & $3.29 \mathrm{~m}$ \\
\hline 3"' & $3.44 \mathrm{~m}$ & $3.60 \mathrm{~m}$ & $3.35 \mathrm{~m}$ & $3.46 \mathrm{~m}$ \\
\hline 4"' & $3.31 \mathrm{~m}$ & $3.50 \mathrm{~m}$ & $3.45 \mathrm{~m}$ & $3.42 \mathrm{~m}$ \\
\hline 5"' & $3.47 \mathrm{~m}$ & $3.69 \mathrm{~m}$ & $3.24 \mathrm{~m}$ & $3.31 \mathrm{~m}$ \\
\hline 6"' & $3.88 \mathrm{~m}, 3.70 \mathrm{~m}$ & $1.2 \mathrm{~d}(6.5)$ & $3.81 \mathrm{~m}, 3.66 \mathrm{~m}$ & $3.67 \mathrm{~m}, 3.50 \mathrm{~m}$ \\
\hline 1"'" & & & $4.58 \mathrm{~d}(1.2)$ & \\
\hline 2"'" & & & $3.69 \mathrm{~m}$ & \\
\hline 3"' & & & $3.46 \mathrm{~m}$ & \\
\hline & & & $3.38 \mathrm{~m}$ & \\
\hline
\end{tabular}




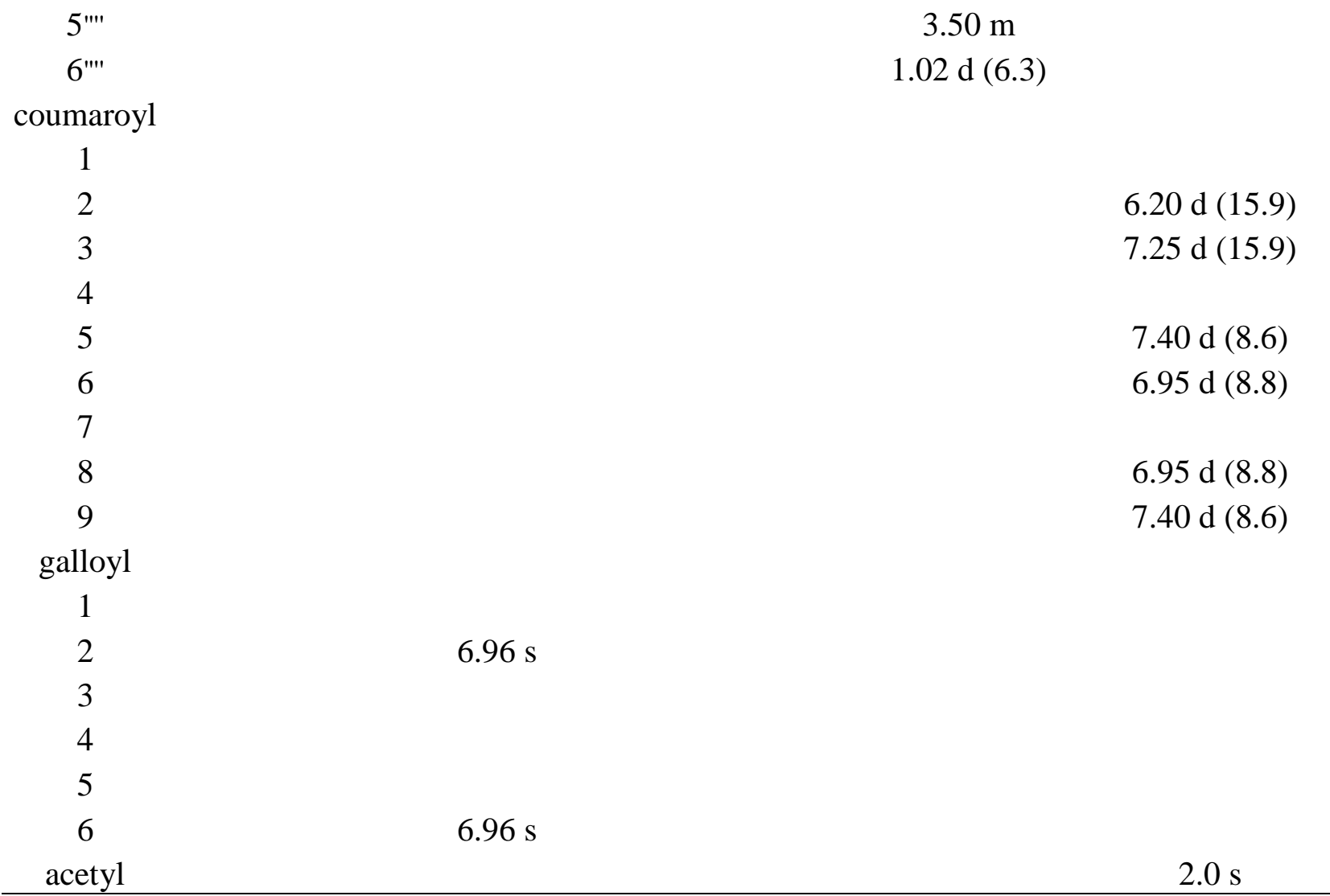

Compound 6 was a colorless amorphous powder $\left(\mathrm{MeOH}-\mathrm{H}_{2} \mathrm{O}, 19: 1\right),[\alpha]_{\mathrm{D}}{ }^{24}-19^{0}(\mathrm{MeOH}, \mathrm{c}$ 0.05 ) and assigned a molecular formula $\mathrm{C}_{57} \mathrm{H}_{88} \mathrm{O}_{24}$, deduced from the sodiated $[\mathrm{M}+\mathrm{Na}]^{+}$ion at $\mathrm{m} / z$ 1179.4533 in the positive HRESI-MS, as well as from its NMR spectroscopic data (Tables 2 and 3). The NMR data were characteristic of oleanane $13 \beta, 28$-olide type-triterpene ${ }^{18,27}$ containing three sugar units [evidenced by anomeric protons, $\delta 4.86(\mathrm{~d}, J=7.8 \mathrm{~Hz}), 4.63(\mathrm{~d}, J=7.4 \mathrm{~Hz})$ and $4.56(\mathrm{~d}$, $J=7.7 \mathrm{~Hz})]$, two acetoxy groups $[\delta 2.10$ and 2.06, both singlets] and angeloyl substituent $[\delta 5.70(\mathrm{~d}$, $J=7.1 \mathrm{~Hz}$ ), 1.84 (d, $J=7.3 \mathrm{~Hz}, \beta$-methyl) and 1.74 (s, $\alpha$-methyl)]. The existence of the angeolyl function was further substantiated by ${ }^{13} \mathrm{C}$ NMR peaks at $\delta 169.9$ (ester carbonyl), 137.6 (methine), 128.7 (quaternary carbon), 22.0 and 17.1 (methyl resonances). ${ }^{7}$ In fact, the ${ }^{1} \mathrm{H}$ and ${ }^{13} \mathrm{C}$ NMR data of 6 closely resembled those of maesasaponin IV previously isolated from Maesa lanceolata native to Rwanda, ${ }^{6}$ with major structural differences being the presence of $13 \beta, 28$-olide group [evidenced by ${ }^{13} \mathrm{C}$ NMR peaks at $\delta 179.8$ (C-28) and 93.3 (C-13)] and the type of oligosaccharide present; an assignment corroborated by HMBC correlations between $\mathrm{H}-22(\delta 5.06) / \mathrm{H}-16(\delta 5.11)$ with C-28 $(\delta 179.8)$ and between $\mathrm{H}-18(\delta 2.20) / \mathrm{H}-19(\delta$ 1.36) with C-13 $(\delta$ 93.3). Detailed NMR spectroscopic data analysis suggested the aglycone of $\mathbf{6}$ to be $3 \beta$-hydroxy-16 $\alpha$, $22 \alpha$-diacetoxy-21 $\beta$-angelolyloleanane- $13 \beta, 28$-olide ${ }^{6}$. This was further supported by the ${ }^{1} \mathrm{H}$ NMR spectrum signals at $\delta 5.11$ ( $\delta 70.2$ in DEPT and HSQC), $\delta 5.06$ ( $\delta 73.7$ in DEPT and HSQC) and $\delta$ 5.30 ( $\delta 76.2$ in DEPT and HSQC), which were ascribable to 16, 22 and 21-protons, respectively. The relative configurations at positions C-3, C-16, C-21 and C-22 were deduced by ${ }^{1} \mathrm{H},{ }^{13} \mathrm{C}$ NMR 
and NOESY spectra. In the ${ }^{13} \mathrm{C}$ NMR spectrum, a peak at $\delta 82.9$ indicated glycosidation site as previously reported for C-3 linked glycosides. ${ }^{20}$ The proton, H-3 correlated with C-23 and in turn with $\mathrm{H}-5$ of the aglycone nucleus in the NOESY spectrum, indicating the $\beta$-configuration of the C-3 substituent. Cross-peak between $\mathrm{H}-22$ and Me-30 inferred the $\alpha$-configuration of the acetyl group at C-22. H-21 correlated with Me-29 and this implies the presence of $\beta$-configuration of the angeloyl group at position $\mathrm{C}-21$, a fact that was confirmed by HMBC correlation between $\mathrm{H}-21$ and the angeloyl carbonyl peak, thus suggesting a 21,22-trans-stereochemistry. Similarly, the $\alpha$-configuration of the acetyl group at C-16 was evident from NOESY correlation peaks between $\mathrm{H}-16$ and $\mathrm{H}-15 \beta$.

Acid hydrolysis afforded glucose as the main sugar residue confirmed by TLC and PC co-chromatography with an authentic sample and GC analysis. ${ }^{28}$ The sequence of the sugar chain at $\mathrm{C}-3$ was determined by analysis of ${ }^{13} \mathrm{C}$ NMR and $\mathrm{HMBC}$ spectra. In the ${ }^{13} \mathrm{C} \mathrm{NMR}$ spectra the downfield peaks at $\delta 83.4$ (glc I-C-4') and 82.3 (glc I-C-2') in comparison to kaempferol triglycoside ${ }^{29}$ suggested that the inner glucose is glycosidated at positions C-2 and C-4 by two other glucose molecules. This was further confirmed by the HMBC experiments which showed correlations between the anomeric protons of glucose at $\delta 4.63$ (glc-II-H-1") with the glucose I-C-2 $(\delta 82.3)$, thus suggesting glucopyranosyl-(1" $\rightarrow 2$ ')-glucopyranosyl bioside previously observed in kaempferol 7-O-rhamnopyranosylsophoroside. ${ }^{21}$ The other HMBC cross-peak between $\delta 4.56$ (glc-III-H-1"') and $\delta 83.4$ (glc-I-C-4') signified the glucopyranosyl-(1'" $\rightarrow 4$ ')-glucopyranosyl arrangement. ${ }^{29}$ Thus, the accrued spectroscopic evidence suggested that the trisaccharide is [glucopyranosyl-(1" $\left.\rightarrow 2^{\prime}\right)$ ][glucopyranosyl-(1'"- $\left.\rightarrow 4^{\prime}\right)$ ]-glucopyranosyl attached at C-3, confirmed by HMBC correlation between $\delta 4.63$ (glc-I-H-1') and $\delta 82.9$ (C-3). Therefore on the basis of spectroscopic analysis, the structure of compound $\mathbf{6}$ was concluded to be

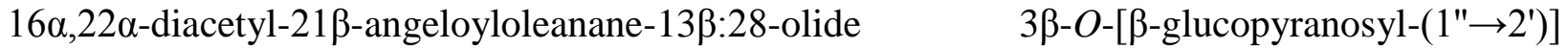
$[\beta$-glucopyranosyl- $(1 ' " \rightarrow 4 ')]$ - $\beta$-glucopyranoside.

Compound 7, analyzed for $\mathrm{C}_{52} \mathrm{H}_{84} \mathrm{O}_{19} \quad\left(\mathrm{~m} / \mathrm{z}, 1035.3921 \quad[\mathrm{M}+\mathrm{Na}]^{+}\right)$exhibited hydroxyl (3430-3250 $\left.\mathrm{cm}^{-1}\right)$, carboxylic group $\left(1722 \mathrm{~cm}^{-1}\right)$, an olefinic moiety $\left(1644 \mathrm{~cm}^{-1}\right)$ and glycosidic bond $\left(1041 \mathrm{~cm}^{-1}\right)$ absorption bands in the IR spectrum. Its ${ }^{1} \mathrm{H}$ and ${ }^{13} \mathrm{C}$ NMR data (Tables 2 and 3) closely resembled those of aesculioside IIc previously isolated from Aesculus pavia ${ }^{30}$ with a notable difference being the saccharide unit in the former compound. Detailed NMR spectroscopic data analysis indicated that the aglycone possessed an angeloyl group, evidenced by characteristic ${ }^{1} \mathrm{H}$ NMR peaks at $\delta 5.84(\mathrm{q}, J=7.3 \mathrm{~Hz}), 1.82(\mathrm{~d}, J=7.1 \mathrm{~Hz})$ and $1.76(\mathrm{~s})$, a fact further supported by ${ }^{13} \mathrm{C}$ NMR data $\left(\delta 168.9,136.5,127.9,20.6\right.$ and 16.4). ${ }^{30,31,32,33}$ In the NMR spectrum, the observed downfield chemical shift at $\delta 5.20(\mathrm{~d}, J=10.2 \mathrm{~Hz})$ in comparison to aesculioside Ic ${ }^{30}$ suggested that the angeloyl moiety was attached at this position and on the basis of the HMBC correlation it was assignable to $\mathrm{H}-21$. The proton exhibited cross-peaks with $\mathrm{C}-21$ ( $\delta 77.8)$ and $\mathrm{C}-16(\delta 69.7)$. The stereochemistry of the aglycone was established from NOESY experiments and vicinal coupling of key protons (see Fig. 2 and Table 2). ${ }^{28}$ Acid hydrolysis yielded xylose, glucose and rhamnose as the sugar residues identified by TLC and PC co-chromatography with authentic samples and confirmed by the ${ }^{1} \mathrm{H}$ NMR single proton resonances at $\delta 4.86(\mathrm{~d}, J=6.9 \mathrm{~Hz}), 4.60(\mathrm{~d}, J=7.6 \mathrm{~Hz})$ and 
$4.52(\mathrm{~d}, J=1.2 \mathrm{~Hz})$, respectively. The attachment of the oligosaccharide unit at $\mathrm{C}-3$ of the aglycone was suggested by the downfield shift of the ${ }^{13} \mathrm{C}$ NMR C-3 peak at $\delta 84.6$ and confirmed by HMBC correlation between $\mathrm{H}-3$ and xylose-C-1 ( $\delta$ 105.4). The relative configuration at C-3 was evident from the NOESY cross-peaks between H-3 and Me-23 and also in turn with H-5 of the aglycone, thus indicating the $\beta$-configuration of the $\mathrm{C}-3$ substituent. The sequence of the carbohydrate chain was established from the following HMBC correlations: xylose-C-2 $(\delta 81.9)$ with glucose-H-1" $(\delta$ 4.60) and rhamnose-H-1"' ( $\delta$ 4.52) with glucose-C-6 ( $\delta$ 66.7), thus suggesting glucopyranosyl-(1" $\rightarrow 2$ ')-rhamnopyranosyl-(1"' $\rightarrow 6$ ")-xylopyranoside moiety. Thus, the structure of 7 was established as $16 \alpha, 22 \alpha, 28$-trihydroxy-21 $\beta$-angeloylolean-12-ene $3 \beta$

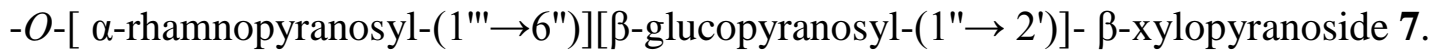

Compound 8, an amorphous colorless powder, had a molecular formula of $\mathrm{C}_{54} \mathrm{H}_{86} \mathrm{O}_{20}$ determined from its sodiated HRESIMS peak at $\mathrm{m} / \mathrm{z} 1077.4532[\mathrm{M}+\mathrm{Na}]^{+},{ }^{13} \mathrm{C}$ NMR and DEPT data. The HRESIMS is 42 units higher than that of compound 7, implying the presence of an acetyl group in the compound, a fact confirmed by the IR absorption peak at $1735 \mathrm{~cm}^{-1}$ and the ${ }^{1} \mathrm{H} \mathrm{NMR}$ signal at $\delta 2.00$ (with corresponding ${ }^{13} \mathrm{C}$ NMR data at $\delta 171.1$ and 23.5 ). In fact, the ${ }^{1} \mathrm{H}$ and ${ }^{13} \mathrm{C}$ NMR and MS data of the compound resembled those of 7, except for the additional peaks from the acetyl functional group, thus indicating the replacement of one hydroxyl group by the acetyl moiety. The downfield chemical shift at $\delta 5.02(\mathrm{~d}, J=9.6 \mathrm{~Hz})$ was assigned to $\mathrm{H}-22$ based on the HMBC cross-peaks between $\mathrm{H}-22$ and C-28 and in turn with C-16, indicating that the acetyl group was at C-22. Acid hydrolysis afforded the aglycone, barringtogenol C, identified by NMR and MS data and comparison with reference data; ${ }^{34,35}$ the three monosaccharides rhamnose, arabinose and galactose, were also identified by the same method as depicted for compound 7. The localization of the oligosaccharide on the aglycone was provided by the ${ }^{13} \mathrm{C}$ NMR (Table 3), which is in complete agreement with those reported for saponariosde $\mathrm{A}^{36}$ and 3-O- $\beta$-D-glucuronopyranosyloleanic acid. ${ }^{37}$ Support for this was provided by HMBC correlation between arabinose anomeric proton at $\delta 4.70(\mathrm{~d}, J=4.4 \mathrm{~Hz})$ with the aglycone $\mathrm{C}-3$ at $\delta$ 83.7.

The sequence of the oligosaccharide chain at C-3 was established by a combination of ${ }^{13} \mathrm{C}$ NMR, HSQC and HMBC experiments. From the completely assigned ${ }^{13} \mathrm{C}-\mathrm{NMR}$, the branched nature of the sugar moiety was evident, and the noticeable ${ }^{13} \mathrm{C}$ shift difference between individual sugar residues and model compounds ${ }^{38}$ suggested that arabinose was the branched centre, while rhamnose and galactose were in terminal positions. In the HMBC spectrum, the following inter-residue correlations were observed: $\mathrm{H}-1^{\prime \prime}$ of rhamnose with $\mathrm{C}-3$ ' of arabinose and $\mathrm{H}-1$ " of galactose with $\mathrm{C}-2^{\prime}$ of arabinose, thus confirming the [ $\beta$-galactopyranosyl$\left.\left(1^{\prime \prime} \rightarrow 2^{\prime}\right)\right][\alpha$-rhamnopyranosyl-(1'" $\rightarrow 4$ ')]- $\alpha$-arabinopyranoside moiety.

The sugar arrangement was further supported by the fragmentation pattern observed in the ESI-MS spectrum (see experimental section). Thus, compound $\mathbf{8}$ was concluded to be $16 \alpha, 28$-dihydroxy-22 $\alpha$-acetyl-21 $\beta$-angeloylolean-12-ene 3-O-[ $\beta$-galactopyranosyl-(1" $\rightarrow 2$ ')] [ $\alpha$-rhamnopyranosyl-(1"' $\rightarrow$ 4')]- $\alpha$-arabinopyranoside. 
I)<smiles>C=CC1=C(C)C=CC2(C)C1CC(C)(C)C(OC(C)=O)C2O</smiles>

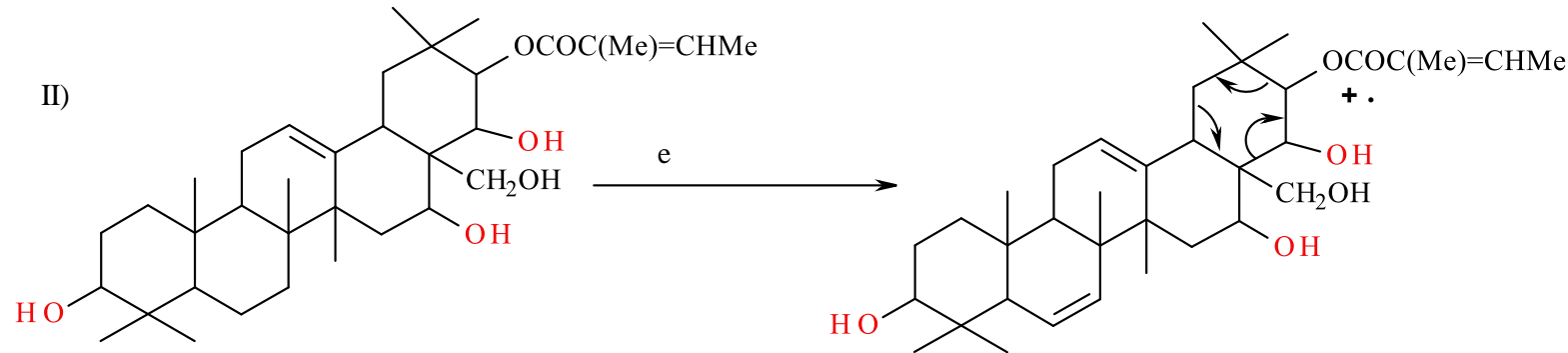<smiles>CC(C)=CCCC1C=C(CO)C(C)CC2(C)C1CCC1(C)C3CCC(O)C(C)(C)C3CCC21C</smiles>

Figure 3. Fragments ions observed in the EIMS spectrum of 7. 
Table 2. ${ }^{1} \mathrm{H}$ NMR (DMSO- $\mathrm{d}_{6}$ ) of compounds 6-8

\begin{tabular}{|c|c|c|c|}
\hline $\mathrm{C}$ & 6 & 7 & 8 \\
\hline 1 & $1.69 \mathrm{~m}, 0.90 \mathrm{~m}$ & $1.66 \mathrm{~m}, 0.84 \mathrm{~m}$ & $1.72 \mathrm{dt}(14.0,5.3), 0.87 \mathrm{~m}$ \\
\hline 2 & $1.91 \mathrm{~m}, 1.84 \mathrm{~m}$ & $1.98 \mathrm{~m}, 1.90 \mathrm{~m}$ & $2.01 \mathrm{~m}, 1.88 \mathrm{~m}$ \\
\hline 3 & $3.58 \mathrm{dd}(11.6,4.0)$ & $3.62 \mathrm{dd}(11.4,3.7)$ & $3.56 \mathrm{dd}(11.6,4.2)$ \\
\hline 4 & & & - \\
\hline 5 & $0.76 \mathrm{~d}(11.4)$ & $0.67 \mathrm{~d}(11.7)$ & $0.78 \mathrm{~d}(12.1)$ \\
\hline 6 & $1.49 \mathrm{~m}, 1.31 \mathrm{~m}$ & $1.55 \mathrm{~m}, 1.30 \mathrm{~m}$ & $1.57 \mathrm{~m}, 1.27 \mathrm{~m}$ \\
\hline 7 & $1.65 \mathrm{~m}, 1.18 \mathrm{~m}$ & $1.69 \mathrm{~m}, 1.36 \mathrm{~m}$ & $1.67 \mathrm{~m}, 1.34 \mathrm{~m}$ \\
\hline \multicolumn{4}{|c|}{ 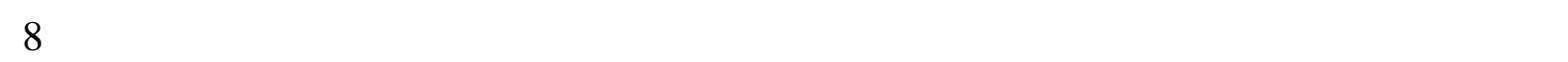 } \\
\hline 9 & $1.34 \mathrm{~m}$ & $1.74 \mathrm{~m}$ & $1.76 \mathrm{~m}$ \\
\hline \multicolumn{4}{|l|}{10} \\
\hline 11 & $1.78 \mathrm{~m}, 1.48 \mathrm{~m}$ & $\begin{array}{c}1.92 \text { ddd }(18.2,7.4,4.2) \\
1.83 \mathrm{~m}\end{array}$ & $\begin{array}{c}1.95 \operatorname{ddd}(18.6,8.0,4.0), 1.86 \\
\operatorname{ddd}(18.6,12.4,3.6)\end{array}$ \\
\hline 12 & $1.94 \mathrm{~m}, 1.54 \mathrm{~m}$ & $5.40 \mathrm{t}(4.1)$ & $5.38 \mathrm{t}(4.1)$ \\
\hline \multicolumn{4}{|l|}{13} \\
\hline \multicolumn{4}{|l|}{14} \\
\hline 15 & $1.98 \mathrm{~m}, 1.64 \mathrm{~m}$ & $1.97 \mathrm{~m}, 1.68 \mathrm{~m}$ & $2.11 \mathrm{~d}(11.2), 1.71 \mathrm{~m}$ \\
\hline 16 & $5.11 \mathrm{br} \mathrm{s}$ & $4.90 \mathrm{~m}$ & $4.80 \mathrm{~m}$ \\
\hline \multicolumn{4}{|l|}{17} \\
\hline 18 & $2.20 \mathrm{dd}(13.6,3.8)$ & $2.29 \mathrm{~d}(11.6)$ & $2.35 \mathrm{~d}(10.8)$ \\
\hline 19 & $2.56 \mathrm{~m}, 1.36 \mathrm{~m}$ & $2.56 \mathrm{~d}(13.8)$ & $2.48 \mathrm{~d}(13.6)$ \\
\hline \multicolumn{4}{|c|}{ - } \\
\hline 21 & $5.30 \mathrm{~d}(10.0)$ & $5.20 \mathrm{~d}(10.2)$ & $4.69 \mathrm{~d}(9.8)$ \\
\hline 22 & $5.06 \mathrm{~d}(10.0)$ & $4.81 \mathrm{~d}(9.6)$ & $5.02 \mathrm{~d}(9.6)$ \\
\hline 23 & $1.22 \mathrm{~s}$ & $1.22 \mathrm{~s}$ & $1.13 \mathrm{~s}$ \\
\hline 24 & $0.88 \mathrm{~s}$ & $1.04 \mathrm{~s}$ & $1.07 \mathrm{~s}$ \\
\hline 25 & $0.97 \mathrm{~s}$ & $0.85 \mathrm{~s}$ & $0.87 \mathrm{~s}$ \\
\hline 26 & $1.24 \mathrm{~s}$ & $1.24 \mathrm{~s}$ & $1.28 \mathrm{~s}$ \\
\hline 27 & $1.27 \mathrm{~s}$ & $1.15 \mathrm{~s}$ & $1.25 \mathrm{~s}$ \\
\hline 28 & & $3.90 \mathrm{~d}(9.2), 3.67 \mathrm{~d}(9.2)$ & $3.85 \mathrm{~d}(10.6), 3.60 \mathrm{~d}(10.6)$ \\
\hline 29 & $0.86 \mathrm{~s}$ & $0.93 \mathrm{~s}$ & $0.90 \mathrm{~s}$ \\
\hline 30 & $0.90 \mathrm{~s}$ & $1.15 \mathrm{~s}$ & $1.12 \mathrm{~s}$ \\
\hline $1^{\prime}$ & $4.86 \mathrm{~d}(7.8)$ & $4.86 \mathrm{~d}(6.9)$ & $4.70 \mathrm{~d}(4.4)$ \\
\hline $2^{\prime}$ & $3.40 \mathrm{~s}$ & $3.26 \mathrm{dd}(9.0,7.6)$ & $3.76 \mathrm{~m}$ \\
\hline $3^{\prime}$ & $3.51 \mathrm{t}(8.8)$ & $3.37 \mathrm{t}(9.5)$ & $3.35 \mathrm{~m}$ \\
\hline $4^{\prime}$ & $3.42 \mathrm{~m}$ & $3.54 \mathrm{t}(9.5)$ & $3.56 \mathrm{~m}$ \\
\hline $5^{\prime}$ & $3.33 \mathrm{~m}$ & $3.32 \mathrm{dd}(11.0,9.0)$ & $3.31 \mathrm{~m}, 3.28 \mathrm{~m}$ \\
\hline $6^{\prime}$ & $3.81 \mathrm{~m}, 3.60 \mathrm{~m}$ & & \\
\hline $1 "$ & $4.63 \mathrm{~d}(7.4)$ & $4.60 \mathrm{~d}(7.6)$ & $4.72 \mathrm{~d}(7.3)$ \\
\hline
\end{tabular}




\begin{tabular}{|c|c|c|c|}
\hline $2 "$ & $3.34 \mathrm{~m}$ & $3.35 \mathrm{dd}(9.0,8.6)$ & $3.51 \mathrm{dd}(9.0,8.3)$ \\
\hline $3 "$ & $3.48 \mathrm{~m}$ & $3.45 \mathrm{t}(9.0)$ & $3.49 \mathrm{dd}(9.1,8.4)$ \\
\hline $4 "$ & $3.39 \mathrm{~m}$ & $3.36 \mathrm{t}(9.0)$ & $3.57 \mathrm{~m}$ \\
\hline $5 "$ & $3.32 \mathrm{~m}$ & $3.38 \mathrm{~m}$ & $3.34 \mathrm{~m}$ \\
\hline 6" & $3.76 \mathrm{~m}, 3.62 \mathrm{~m}$ & $\begin{array}{l}3.82 \mathrm{dd}(12.2,3.4) \\
3.64 \mathrm{dd}(12.0,5.4)\end{array}$ & $\begin{array}{c}3.77 \text { dd }(12.4,3.5), \\
3.55(12.4,5.0)\end{array}$ \\
\hline $1 " '$ & $4.56 \mathrm{~d}(7.7)$ & $4.52 \mathrm{~d}(1.2)$ & $4.54 \mathrm{~d}(1.2)$ \\
\hline 2"' & $3.37 \mathrm{~m}$ & $3.40 \mathrm{dd}(9.0,7.5)$ & $3.52 \mathrm{~m}$ \\
\hline 3"' & $3.50 \mathrm{~m}$ & $3.56 \mathrm{t}(8.8)$ & $3.29 \mathrm{~m}$ \\
\hline 4"' & $3.47 \mathrm{~m}$ & $3.33 \mathrm{t}(9.0)$ & $3.24 \mathrm{~m}$ \\
\hline $5 " '$ & $3.36 \mathrm{~m}$ & $3.28 \mathrm{~m}$ & $3.84 \mathrm{~m}$ \\
\hline 6"' & $3.80 \mathrm{~m}, 3.66 \mathrm{~m}$ & $\begin{array}{l}3.80 \mathrm{dd}(11.0,5.0), \\
3.66 \mathrm{dd}(11.0,3.3)\end{array}$ & $1.0 \mathrm{~d}(6.5)$ \\
\hline \multicolumn{3}{|c|}{ angeloyl } & \\
\hline 2'"'-Me & $1.74 \mathrm{~s}$ & $1.76 \mathrm{~s}$ & $1.78 \mathrm{~s}$ \\
\hline 3"' & $5.70 \mathrm{q}(7.1)$ & $5.84 \mathrm{q}(7.3)$ & $5.76 \mathrm{q}(7.2)$ \\
\hline 4"'" & $1.84 \mathrm{~d}(7.3)$ & $1.82 \mathrm{~d}(7.1)$ & $1.86 \mathrm{~d}(7.3)$ \\
\hline OAc & $2.10 \mathrm{~s}, 2.06 \mathrm{~s}$ & & $2.00 \mathrm{~s}$ \\
\hline
\end{tabular}

Table 3. ${ }^{13} \mathrm{C}$ NMR of compounds $\mathbf{1 - 8}$

\begin{tabular}{ccccccccc}
\hline Carbon & $\mathbf{1}$ & $\mathbf{2}$ & $\mathbf{3}$ & $\mathbf{4}$ & $\mathbf{5}$ & $\mathbf{6}$ & $\mathbf{7}$ & $\mathbf{8}$ \\
\hline 1 & 39.2 & 39.5 & 38.9 & 38.5 & 39.9 & 38.6 & 38.8 & 39.0 \\
2 & 27.7 & 26.4 & 25.8 & 27.1 & 26.8 & 27.4 & 26.7 & 26.5 \\
3 & 81.4 & 80.1 & 82.9 & 83.5 & 83.1 & 82.9 & 84.6 & 83.7 \\
4 & 40.8 & 38.6 & 40.0 & 38.7 & 39.1 & 40.1 & 39.8 & 39.6 \\
5 & 56.1 & 55.3 & 57.1 & 55.2 & 56.0 & 55.6 & 55.6 & 55.8 \\
6 & 18.6 & 18.2 & 19.0 & 18.6 & 18.2 & 18.5 & 18.0 & 18.3 \\
7 & 33.7 & 32.8 & 33.5 & 31.8 & 33.5 & 33.7 & 33.0 & 32.9 \\
8 & 40.8 & 41.4 & 41.0 & 40.8 & 39.7 & 41.0 & 40.4 & 40.2 \\
9 & 48.3 & 47.6 & 48.5 & 47.1 & 47.6 & 48.4 & 47.1 & 46.6 \\
10 & 37.2 & 36.9 & 36.8 & 36.9 & 37.0 & 36.8 & 36.6 & 36.4 \\
11 & 23.6 & 23.7 & 24.5 & 23.4 & 19.1 & 18.9 & 23.6 & 23.8 \\
12 & 123.1 & 122.3 & 123.5 & 124.8 & 30.8 & 31.3 & 123.5 & 124.1 \\
13 & 145.6 & 145.5 & 144.6 & 144.3 & 92.6 & 93.3 & 143.6 & 142.5 \\
14 & 42.4 & 43.0 & 42.8 & 41.4 & 42.4 & 42.0 & 42.0 & 41.5 \\
15 & 45.0 & 35.2 & 36.3 & 33.1 & 37.2 & 37.5 & 33.8 & 34.0 \\
16 & 214.0 & 70.4 & 71.2 & 69.7 & 70.6 & 70.2 & 69.7 & 68.8 \\
17 & 57.0 & 40.5 & 49.6 & 56.8 & 48.3 & 47.9 & 48.3 & 48.1 \\
18 & 47.0 & 42.9 & 40.8 & 39.4 & 51.1 & 50.8 & 41.2 & 40.4
\end{tabular}




\begin{tabular}{|c|c|c|c|c|c|c|c|c|}
\hline 19 & 46.9 & 49.0 & 47.9 & 46.5 & 38.8 & 38.5 & 48.0 & 47.7 \\
\hline 20 & 31.5 & 31.4 & 31.0 & 32.1 & 36.6 & 35.9 & 36.0 & 36.4 \\
\hline 21 & 37.0 & 37.5 & 39.8 & 43.6 & 75.6 & 76.2 & 77.8 & 75.4 \\
\hline 22 & 32.3 & 70.2 & 71.4 & 74.4 & 74.6 & 73.7 & 72.8 & 76.6 \\
\hline 23 & 28.7 & 27.9 & 28.3 & 28.6 & 27.4 & 27.3 & 27.4 & 27.6 \\
\hline 24 & 16.8 & 16.6 & 16.9 & 15.4 & 15.8 & 15.9 & 17.1 & 16.6 \\
\hline 25 & 16.6 & 15.9 & 16.1 & 16.5 & 16.0 & 16.4 & 15.8 & 15.4 \\
\hline 26 & 18.3 & 17.6 & 18.0 & 17.2 & 17.6 & 18.0 & 17.0 & 16.5 \\
\hline 27 & 26.8 & 27.4 & 27.1 & 26.6 & 26.5 & 26.3 & 26.6 & 27.0 \\
\hline 28 & 70.6 & 66.5 & 69.3 & 203.3 & 180.4 & 179.8 & 67.7 & 66.5 \\
\hline 29 & 33.8 & 29.8 & 32.0 & 30.9 & 29.3 & 29.2 & 30.4 & 29.7 \\
\hline 30 & 25.0 & 25.3 & 26.0 & 19.9 & 20.4 & 21.3 & 20.5 & 21.0 \\
\hline $1^{\prime}$ & 103.6 & 104.6 & 102.1 & 104.2 & 104.4 & 103.3 & 105.4 & 104.6 \\
\hline $2^{\prime}$ & 76.4 & 82.4 & 81.1 & 81.4 & 82.0 & 82.3 & 81.9 & 82.4 \\
\hline $3^{\prime}$ & 77.8 & 76.0 & 76.7 & 82.5 & 77.7 & 76.7 & 71.0 & 81.8 \\
\hline $4^{\prime}$ & 70.7 & 69.9 & 71.0 & 74.6 & 70.1 & 83.4 & 83.8 & 73.0 \\
\hline $5^{\prime}$ & 77.3 & 77.3 & 78.0 & 65.8 & 75.6 & 74.7 & 62.1 & 64.3 \\
\hline $6^{\prime}$ & 67.3 & 68.1 & 69.5 & & 67.5 & 62.3 & & \\
\hline $1 "$ & 102.8 & 102.4 & 101.3 & 102.1 & 103.5 & 101.4 & 102.1 & 101.3 \\
\hline $2^{\prime \prime}$ & 75.3 & 75.5 & 75.0 & 81.4 & 76.4 & 75.8 & 72.8 & 74.5 \\
\hline 3" & 77.7 & 77.0 & 77.0 & 76.9 & 78.2 & 78.0 & 74.6 & 76.6 \\
\hline 4" & 71.1 & 70.1 & 69.8 & 69.8 & 69.5 & 71.2 & 69.8 & 69.3 \\
\hline 5" & 76.9 & 77.8 & 78.0 & 77.3 & 77.2 & 77.6 & 76.3 & 77.5 \\
\hline 6" & 61.8 & 61.3 & 61.3 & 62.3 & 68.5 & 61.5 & 66.7 & 60.4 \\
\hline $1 " '$ & & 103.8 & 100.8 & 101.1 & 102.5 & 100.9 & 99.8 & 100.4 \\
\hline $2^{\prime \prime \prime}$ & & 76.8 & 70.0 & 74.9 & 75.6 & 75.1 & 69.8 & 70.4 \\
\hline 3"' & & 77.4 & 71.0 & 77.0 & 77.8 & 77.8 & 70.2 & 70.6 \\
\hline 4"' & & 71.2 & 72.8 & 70.1 & 70.5 & 70.3 & 71.2 & 71.4 \\
\hline 5"' & & 75.9 & 68.4 & 77.8 & 78.3 & 78.1 & 69.3 & 68.5 \\
\hline 6"' & & 69.5 & 17.4 & 68.1 & 61.4 & 62.0 & 17.7 & 17.8 \\
\hline $1 " ' "$ & & & & 100.7 & & & & \\
\hline $2^{\prime \prime \prime \prime}$ & & & & 70.8 & & & & \\
\hline 3"'" & & & & 71.3 & & & & \\
\hline 4"' & & & & 73.0 & & & & \\
\hline $5^{\prime \prime \prime}$ & & & & 69.2 & & & & \\
\hline 6"' & & & & 17.4 & & & & \\
\hline \multicolumn{9}{|c|}{ galloyl } \\
\hline 1 & & 121.1 & & & & & & \\
\hline 2 & & 112.3 & & & & & & \\
\hline 3 & & 148.1 & & & & & & \\
\hline
\end{tabular}




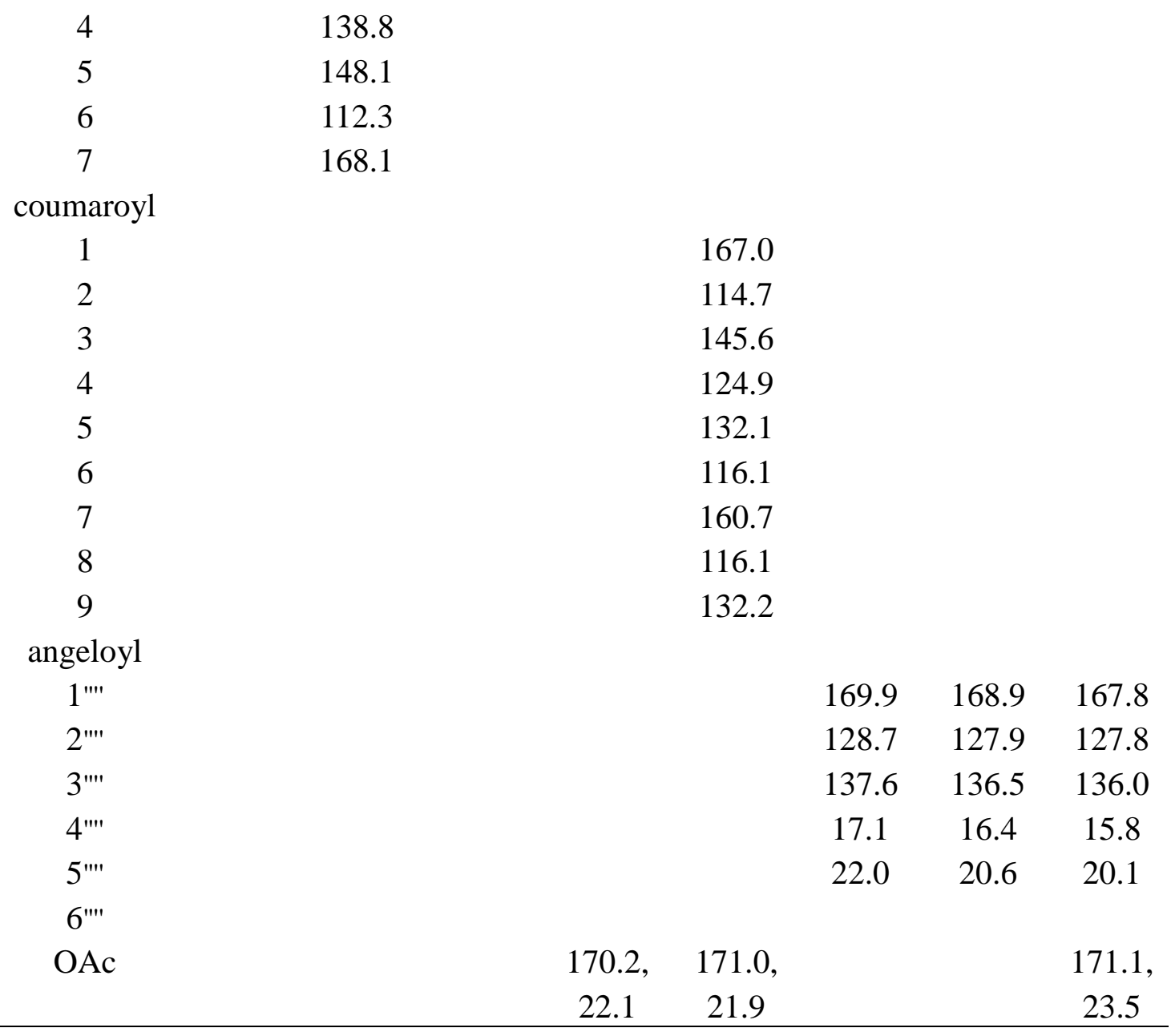

\section{Antibacterial activity}

Biologically active compounds are responsible for plants resistance against bacteria, fungi, viruses and other pests and this is demonstrated by the antibacterial activities reported in this study. The $\mathrm{MeOH}$ extract and pure isolates were assayed using eight clinically isolated bacteria comprising of four Gram +Ve (Staphylococcus aureus, Bacilus subtilis, Streptococcus pneumoniae and Enterococcus faecalis (syn:Streptococcus faecalis) and four Gram -Ve (Salmonella typhii, Vibro cholerae, Eschericia coli and Pseudomonas aeruginosa). The $\mathrm{MeOH}$ extract of the plant showed varying degree of antibacterial activities against the tested bacteria species (Table 4) with promising result being recorded for $V$. cholerae (inhibition zone $(28 \pm 0.1 \mathrm{~mm})$ compared to other bacteria. This was followed closely by $S$. typhii which gave an inhibition zone of $26 \pm 0.2 \mathrm{~mm}$. The pathogens $S$. aureus, B. subtilis and Enterococcus faecalis were found to be moderately sensitive with inhibition zones of $22 \pm 0.3,20 \pm 0.4$ and $18 \pm 0.0 \mathrm{~mm}$, respectively. These results were found to be comparable to the standard antibiotics gentamycin and streptomycin which were used as the reference drugs. The microorganisms' $P$. aeruginosa and $E$. coli were observed to be less susceptible with inhibition zone of $14 \pm 0.2$ and $10 \pm 0.2 \mathrm{~mm}$, respectively. The behaviors of $E$. coli and $P$. aeroginosa could be as a result of enzyme destroying or inactivating the bioactive 
phytoconstituents. The activities appeared to be broad spectrum because it was independent on the gram reaction.

The minimum inhibitory concentration (MIC) of the extract, pure compounds and the standard antibiotics are shown in Table 5. The MIC values for the extract against the organisms ranged between 100 and $1000 \mu \mathrm{g} / \mathrm{ml}$ with the highest activity of $100 \mu \mathrm{g} / \mathrm{ml}$ recorded for $V$. cholerae, while the value for $S$. typhii was $125 \mu \mathrm{g} / \mathrm{ml}$. The gram positive bacteria $S$. aureus and B. subtilis gave MIC values 200 and $250 \mu \mathrm{g} / \mathrm{ml}$, respectively while E. faecalis and $S$. pneumoniae both exhibited a MIC value of $500 \mu \mathrm{g} / \mathrm{ml}$. The gram -Ve P. aeruginosa showed gave a MIC value of $500 \mu \mathrm{g} / \mathrm{ml}$ while that for E. coli was $1000 \mu \mathrm{g} / \mathrm{ml}$.

Out of the 17 compounds isolated only four $(\mathbf{5}, \mathbf{6}, \mathbf{7}$ and $\mathbf{8})$ showed activities against five strains of the microorganisms tested. Compound $\mathbf{6}$ was the most active and its MIC values ranged between $62.5-200 \mu \mathrm{g} / \mathrm{ml}$ with the highest activity reported for $V$. cholerae (MIC value $62.5 \mu \mathrm{g} / \mathrm{ml}$ ). The compound was also found to be fairly potent to both $S$. aureus and $S$. typhii with MIC values 125 and $100 \mu \mathrm{g} / \mathrm{ml}$, respectively. Compound 7 and $\mathbf{8}$ were the other metabolites with encouraging activities against some of the microorganisms studied. In this respect, compound 7 was more active than compound $\mathbf{8}$ with promising results being reported for $S$. typhii and $V$. cholerae exhibiting MIC values of 100 and $125 \mu \mathrm{g} / \mathrm{ml}$, respectively. Compound 7 also exhibited a MIC value of $200 \mu \mathrm{g} / \mathrm{ml}$ for both $S$. pneumoniae and E. faecalis. The compound was, however, not active to $S$. aureus, B. subtilis, E. coli and $P$. aeruginosa even at greater than $200 \mu \mathrm{g} / \mathrm{ml}$ concentration. Compound 8, on other hand afforded MIC values of $200 \mu \mathrm{g} / \mathrm{ml}$ against $S$. typhii, $V$. cholerae and B. subtilis. The rest of the microorganisms were inactive to the secondary metabolite. Compound 5 was only active to $S$. aureus with MIC value of $200 \mu \mathrm{g} / \mathrm{ml}$. The gram negative were more susceptible to the extract and pure metabolites, thus the demonstrated activity against the tested bacteria provides scientific basis for the local usage of the plant in the treatment of cholera ${ }^{6}$.

Table 4. Antibacterial susceptibility tests

\begin{tabular}{ccccccccc}
\hline $\begin{array}{c}\text { Extract/ } \\
\text { compounds }\end{array}$ & \multicolumn{3}{c}{ Gram +Ve bacteria } & \multicolumn{5}{c}{ Gram - Ve bacteria } \\
\hline & $\mathrm{Sa}$ & $\mathrm{Bs}$ & $\mathrm{Sp}$ & $\mathrm{Ef}$ & $\mathrm{Vc}$ & $\mathrm{St}$ & $\mathrm{Ec}$ & $\mathrm{Pa}$ \\
MeOH ext. & $22 \pm 0.3$ & $20 \pm 0.4$ & $14 \pm 1.0$ & $18 \pm 0.0$ & $28 \pm 0.1$ & $26 \pm 0.2$ & $10 \pm 0.2$ & $14 \pm 0.2$ \\
Gentamycin & $27 \pm 1.3$ & $26 \pm 1.0$ & $16 \pm 0.3$ & $26 \pm 1.0$ & $28 \pm 0.1$ & $32 \pm 0.7$ & $28 \pm 0.4$ & $24 \pm 0.00$ \\
Streptomycin & $24 \pm 0.3$ & $22 \pm 1.3$ & $18 \pm 1.1$ & $26 \pm 2.0$ & $28 \pm 0.3$ & $26 \pm 1.1$ & $25 \pm 1.0$ & $26 \pm 0.3$ \\
\hline
\end{tabular}

$\mathrm{Sa}=$ Staphylococcus aureus, $\mathrm{Bs}=$ Bacilus subtilis, $\mathrm{Sp}=$ Streptococcus pneumoniae, Ef= Enterococcus faecalis, $\mathrm{Vc}=$ Vibro cholerae, $\mathrm{St}=$ Salmonella typhii, $\mathrm{Ec}=$ Escherichia coli, $\mathrm{Pa}=$ Pseudomonas aeruginosa. 
Table 5. Minimum inhibitory concentration (MIC, $\mu \mathrm{g} / \mathrm{ml}$ for extract and pure Compounds)

\begin{tabular}{ccccccccc}
\hline $\begin{array}{c}\text { MeOH } \\
\text { extract/ } \\
\text { compounds }\end{array}$ & \multicolumn{3}{c}{ Gram + Ve bacteria } & & \multicolumn{3}{c}{ Gram - Ve bacteria } \\
\hline Sa & $\mathrm{Bs}$ & $\mathrm{Sp}$ & $\mathrm{Ef}$ & $\mathrm{Vc}$ & $\mathrm{St}$ & $\mathrm{Ec}$ & $\mathrm{Pa}$ \\
$\mathrm{MeOH}$ extract & 200 & 250 & 500 & 500 & 100 & 125 & 1000 & 500 \\
$\mathbf{6}$ & 125 & 200 & 200 & 200 & 62.5 & 100 & 200 & 200 \\
$\mathbf{7}$ & $\mathrm{NA}$ & $\mathrm{NA}$ & 200 & 200 & 125 & 100 & $\mathrm{NA}$ & $\mathrm{NA}$ \\
$\mathbf{8}$ & $\mathrm{NA}$ & 200 & $\mathrm{NA}$ & $\mathrm{NA}$ & 200 & 200 & $\mathrm{NA}$ & $\mathrm{NA}$ \\
$\mathbf{5}$ & 200 & $\mathrm{NA}$ & $\mathrm{NA}$ & $\mathrm{NA}$ & $\mathrm{NA}$ & $\mathrm{NA}$ & $\mathrm{NA}$ & $\mathrm{NA}$ \\
Gentamycin & 0.5 & 1.0 & 1.0 & 5.0 & 4.0 & 1.0 & 1.2 & 3.0 \\
Streptomycin & 2.5 & 4.5 & 5 & 10 & 10.0 & 4.0 & 10 & 2.0 \\
\hline
\end{tabular}

$\mathrm{NA}=$ not active.

\section{Experimental Section}

General. Optical rotations were measured with JASCO DIP-370 digital Polarimeter. Melting points were determined using a Gallenkamp melting apparatus and are uncorrected. The UV and IR data were recorded on PYE UNICAM SP8-150 UV/Vis spectrophotometer and Perkins-Elmer FTIR 600 series. The ESI-MS data were taken in LCQ and JOEL JMS-700 M station mass spectrometer, respectively. EI-MS data were obtained on a MAT 8200 A Varian Bremen instrument. The ${ }^{1} \mathrm{H}$ NMR data were taken in DMSO- $\mathrm{d}_{6}$ and $\mathrm{CDCl}_{3}-\mathrm{DMSO}-\mathrm{d}_{6}$ on a Brucker Ultra-shield-500 spectrometer operating at 500MHz and $125 \mathrm{MHz}$. Preparative high performance liquid chromatography (HPLC) was done on a JASCO model PU-2080 HPLC system equipped with a shodex R1-101 refractive index detector and YMC-pack RP-18 column (150 x20mm i.d).

\section{Plant material}

The leaves of Maesa lanceolata were collected near Kapsoit Trading Centre along the Kisumu-Kericho highway, Kenya in February 2006. Voucher specimens (leaves, fruits and twigs) were identified after comparison with authentic sample at the Botany Department, University of Nairobi.

\section{Extraction and isolation}

Powdered dry leaves approx. $3 \mathrm{~kg}$ was extracted in the cold with aqueous $\mathrm{MeOH}(7.5 \mathrm{~L} \mathrm{x} 3)$ at room temperature for a period of one week under constant agitating using orbital shaker. The resulting extracts were combined and solvent removed under reduced pressure resulting into a dark green residue $\left(850 \mathrm{~g}\right.$ ), which was then partitioned between $\mathrm{n}-\mathrm{BuOH}$ and $\mathrm{H}_{2} \mathrm{O}$. The $\mathrm{n}-\mathrm{BuOH}$ was evaporated at reduced pressure using a rotary evaporator and later freeze dried to give a dark green 
solid material of $540 \mathrm{~g}$. A portion of the extract approx. $350 \mathrm{~g}$ was subjected to pass over sephadex $\mathrm{LH}-20$ using $\mathrm{CH}_{2} \mathrm{Cl}_{2}-\mathrm{MeOH}$ ( $5 \%$ increments of $\mathrm{MeOH}$ ), $\mathrm{MeOH}$ neat and finally with $\mathrm{MeOH}-\mathrm{H}_{2} \mathrm{O}$ (with 10 and $20 \%$ increments of $\mathrm{H}_{2} \mathrm{O}$ ). Three hundred and fifty fractions (each $50 \mathrm{ml}$ ) were sampled and their composition monitored by TLC ( $2 \%$ oxalic acid deactivated silica gel) eluent: $\mathrm{CH}_{2} \mathrm{Cl}_{2}-\mathrm{MeOH}$ (4:1, 2:1 and 1:1) followed by

$\left.\mathrm{CH}_{2} \mathrm{Cl}_{2}-\mathrm{MeOH}-\mathrm{H}_{2} \mathrm{O}, 6: 3: 1\right)$. Those showing similar TLC profiles were combined and this resulted into four major pools (A-D). Pool A (fractions 10-75, $26.5 \mathrm{~g}$ ) was further applied to silica gel column and elution done with $\mathrm{CH}_{2} \mathrm{Cl}_{2}-\mathrm{MeOH}-\mathrm{H}_{2} \mathrm{O}$ (8:1.5:0.5) to give 150 fractions (20 ml each), which were combined into five major fractions (A1-A5) depending on TLC profiles. Fractions A1 to A5 were found to contain mainly flavonoids, combined and further separated by repeated medium pressure chromatography over deactivated silica gel using $\mathrm{CH}_{2} \mathrm{Cl}_{2}-\mathrm{MeOH}$ mixture with increasing concentrations of the more polar solvent, affording quercetin 9 (75 mg), myricetin 10 (69 mg), quercetin 3- $O$-rhamnopyranoside 11 (45 mg), myricetin 3- $O$-glucopyranoside 12 (52 mg), gallic acid $13(125 \mathrm{mg})$ and sistosterol 3-O-glucopyranoside $14(85 \mathrm{mg}){ }^{9}$. Pool B (36 g) was chromatographed over silica gel column with $\mathrm{CH}_{2} \mathrm{Cl}_{2}-\mathrm{MeOH}-\mathrm{H}_{2} \mathrm{O}$ (4:3:0.5) followed by the same solvent system in the ratio 4:3:1 to give three fractions B1-B3. Fraction B1 (5 g) was further purified by repeated preparative HPLC with acetonitrile-MeOH mixture, mobile flow rate $10 \mathrm{~mL}$ $\min ^{-1}$, injecting $10 \mu \mathrm{L}$ each time to afford rutin $15\left(63 \mathrm{mg}, \mathrm{t}_{\mathrm{R}}=19 \mathrm{~min}, 10 \% \mathrm{MeOH}\right)$, quercetin 3, 7- $O$-diglucopyranoside $16\left(25 \mathrm{mg}, \mathrm{t}_{\mathrm{R}}=23 \mathrm{~min}, 15 \% \mathrm{MeOH}\right)^{9}$ and $5\left(49 \mathrm{mg}, \mathrm{t}_{\mathrm{R}}=25 \mathrm{~min}, 20 \%\right.$ $\mathrm{MeOH})$. Fraction B2 (5.6 g) was similarly separated by preparative HPLC using same eluent as for fraction $\mathrm{B} 1$ to give a further compound $\mathbf{5}(18 \mathrm{mg})$ and $\mathbf{1}\left(38 \mathrm{mg}, \mathrm{t}_{\mathrm{R}}=29 \mathrm{~min}, 25 \% \mathrm{MeOH}\right)$. Fraction B3 (8.0 g) upon repeated preparative HPLC using $\mathrm{MeOH}-\mathrm{CH}_{3} \mathrm{CN}$ mixtures at a flow rate of $5 \mathrm{~mL}$ $\min ^{-1}$ gave compound $2\left(55, \mathrm{t}_{\mathrm{R}}=37 \mathrm{~min}, 35 \% \mathrm{MeOH}\right)$ and unidentified compound $\left(5 \mathrm{mg}, \mathrm{t}_{\mathrm{R}}=41\right.$, $40 \% \mathrm{MeOH})$.

Pool C (25 g) was subjected to silica gel column eluting with $\mathrm{CH}_{2} \mathrm{Cl}_{2}-\mathrm{MeOH}-\mathrm{H}_{2} \mathrm{O}(80: 10: 1)$ to give four fractions $\mathrm{C} 1-\mathrm{C} 4$, which were similarly purified by repeated preparative HPLC using aqueous methanol at a flow rate of $5 \mathrm{~mL} \mathrm{~min}^{-1}$ to give compound $6\left(54 \mathrm{mg}, \mathrm{t}_{\mathrm{R}}=22 \mathrm{~min}, 50 \%\right.$ $\mathrm{MeOH})$, myricetin 3-O-glucoside $(1 \rightarrow 3)$-rhamnoside $17\left(33 \mathrm{mg}, \mathrm{t}_{\mathrm{R}}=32 \mathrm{~min}, 55 \% \mathrm{MeOH}\right){ }^{9}$ and compound 3 (68 mg, $\left.\mathrm{t}_{\mathrm{R}}=39 \mathrm{~min}, 60 \% \mathrm{MeOH}\right)$.

Pool D (7.0 g) was applied to silica gel column eluting with $\mathrm{CH}_{2} \mathrm{Cl}_{2}-\mathrm{MeOH}-\mathrm{H}_{2} \mathrm{O}$ (40:10:1) to give four fractions D1-D4 and were further purified using HPLC with aqueous $\mathrm{MeOH}$ at a flow rate of $5 \mathrm{mLmin}^{-1}$ to afforded compound $8\left(60 \mathrm{mg}, \mathrm{t}_{\mathrm{R}}=45 \mathrm{~min}, 75 \% \mathrm{MeOH}\right), 7\left(57 \mathrm{mg}, \mathrm{t}_{\mathrm{R}}=50 \mathrm{~min}, 82.5 \%\right.$ $\mathrm{MeOH})$ and compound $4\left(80 \mathrm{mg}, \mathrm{t}_{\mathrm{R}}=55 \mathrm{~min}, 75 \% \mathrm{MeOH}\right)$.

\section{6-Oxo-28-hydroxyolean-2-ene $\quad 3-O$ - $\beta$-glucopyranosyl-( $\left.1^{\prime \prime} \rightarrow 6^{\prime}\right)$ - $\beta$-glucopyranoside $\quad(1)$.} Amorphous colorless powder; mp 246-248 ${ }^{0} \mathrm{C}$; $[\alpha]_{\mathrm{D}}{ }^{25}-18^{0}(\mathrm{MeOH}, \mathrm{c} 0.06)$; IR (KBr) $v_{\max }$ : 3430-3150 (OH), 2930, 2850, 1705 (C=O), 1642 (C=C), 1455, 1370, 1252, 1080, 1030, $920 \mathrm{~cm}^{-1}$; ${ }^{1} \mathrm{H}$ NMR $\left(500 \mathrm{MHz}, \mathrm{CDCl}_{3}+\right.$ one drop DMSO-d 6 ) $\delta \mathrm{ppm}$ : data see Table $1 ;{ }^{13} \mathrm{C}$ NMR $(125 \mathrm{MHz}$, $\mathrm{CDCl}_{3}+$ one drop DMSO-d 6 ) $\delta$ ppm: data see Table 3; EIMS (70 eV): $\mathrm{m} / z(\%) 456$ (11), 439 (5), 438 (3), 424 (16), 408 (2), $248\left[\mathrm{C}_{16} \mathrm{H}_{24} \mathrm{O}_{2}\right]^{+}$(11\%), 235 (100), 217 (13), $208\left[\mathrm{C}_{14} \mathrm{H}_{24} \mathrm{O}\right]^{+}(25 \%)$, 
$207\left[\mathrm{C}_{14} \mathrm{H}_{23} \mathrm{O}\right]^{+}$(21\%), 187 (41), 95 (93), 69 (83); ESI-MS:m/z $803.2[\mathrm{M}+\mathrm{Na}]^{+}, 657.1$ $[\mathrm{M}+\mathrm{Na}-162]^{+}, 495.3[\mathrm{M}+\mathrm{Na}-2 \times 162]^{+}, 324.2[162+162]^{+}, 162[\mathrm{glc}]^{+}$; HRESIMS: $\mathrm{m} / z$ 803.3456 $[\mathrm{M}+\mathrm{Na}]^{+}$(calcd. for $\mathrm{C}_{42} \mathrm{H}_{68} \mathrm{O}_{4} \mathrm{Na}, 803.3448$ ).

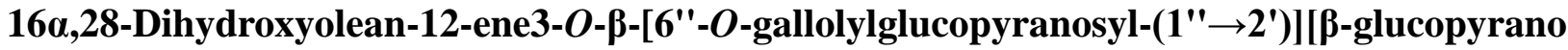
syl-(1"' $\left.\rightarrow \mathbf{6}^{\prime}\right)$ - $\boldsymbol{\beta}$-glucopyranoside (2). Amorphous colorless powder; mp $>250^{\circ} \mathrm{C}$; $[\alpha]_{\mathrm{D}}{ }^{25}-32^{0}$ (MeOH, c 0.05); UV $\lambda_{\max } 202$ (log $\varepsilon$ 3.10) nm; IR $v_{\max }(\mathrm{KBr}): 3460-3100(\mathrm{OH}), 2928,2860,1708$ $(\mathrm{C}=\mathrm{O}), 1644(\mathrm{C}=\mathrm{C}), 1450,1380,1050,1020,960 \mathrm{~cm}^{-1} ;{ }^{1} \mathrm{H}$ NMR (500 MHz, DMSO-d 6 ) $\delta$ ppm: data see Table 1; ${ }^{13} \mathrm{C}$ NMR (125 MHz, DMSO-d 6$) \delta$ ppm: data see Table 3; EI-MS $(70 \mathrm{eV}): \mathrm{m} / z(\%)$ $458\left[\mathrm{C}_{30} \mathrm{H}_{50} \mathrm{O}_{3}\right]^{+}(4), 440\left[\mathrm{C}_{30} \mathrm{H}_{50} \mathrm{O}_{3}-\mathrm{H}_{2} \mathrm{O}\right]^{+}(8), 439$ (7), $422\left[\mathrm{C}_{30} \mathrm{H}_{50} \mathrm{O}_{3}-2 \mathrm{H}_{2} \mathrm{O}\right]^{+}(11), 250$ $\left[\mathrm{C}_{16} \mathrm{H}_{26} \mathrm{O}_{2}\right]^{+}$(33), 249 (21), $232(10), 219\left[\mathrm{C}_{15} \mathrm{H}_{23} \mathrm{O}\right]^{+}$(22), 208 (13), $207\left[\mathrm{C}_{14} \mathrm{H}_{23} \mathrm{O}\right]^{+}$(16), 201 (41), 191 (5), 189 (100), 95 (42), 69 (88); ESI-MS m/z:1119.3 [M+Na] ${ }^{+}$. HRESI-MS: m/z 1119.4926 $[\mathrm{M}+\mathrm{Na}]^{+}$(calcd. for $\mathrm{C}_{55} \mathrm{H}_{84} \mathrm{O}_{22} \mathrm{Na}, 1119.4783$ ).

$16 \alpha, 22 \alpha, 28$-Trihydroxyolean-12-ene-3-O -[ $\beta$-glucopyranosyl-( $\left.\left.1^{\prime \prime} \rightarrow 2^{\prime}\right)\right][\alpha$-rhamnopyranosyl -(1'" $\left.\left.\rightarrow \mathbf{6}^{\prime}\right)\right]$ - $\boldsymbol{\beta}$-glucopyranoside (3). Amorphous colorless powder; mp $>250^{\circ} \mathrm{C} ;[\alpha]_{\mathrm{D}}{ }^{25}-71^{0}(\mathrm{MeOH}$, c 0.1); IR $v_{\max }(\mathrm{KBr}): 3460(\mathrm{OH}), 2932,2850,1635(\mathrm{C}=\mathrm{C}), 1381,1252,1060,1012,870 \mathrm{~cm}^{-1} ;{ }^{1} \mathrm{H}$ NMR (500 MHz, DMSO-d 6 ) $\delta$ ppm: data see Table $1 ;{ }^{13} \mathrm{C} \mathrm{NMR} \mathrm{(125} \mathrm{MHz,} \mathrm{DMSO-d} 6$ ) $\delta$ ppm:

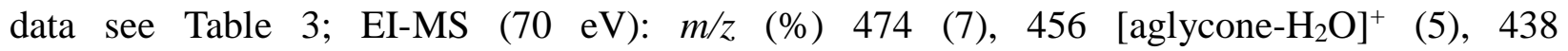
[aglycone- $\left.2 \mathrm{H}_{2} \mathrm{O}\right]^{+}(14), 407$ [aglycone- $\left.2 \mathrm{H}_{2} \mathrm{O}-\mathrm{CH}_{2} \mathrm{OH}\right]^{+}$(5), 248 (100), 235 (9), 218 (10), 217 (15), 208 (13), 207 (23), 206 (4), 201 (20), 189 (35); ESIMS:m/z 967.3 [M+Na] $]^{+}, 821.1$ [M+Na-146] ${ }^{+}$, 659.0 [M+Na- 162-146] $]^{+}, 497[\mathrm{M}+\mathrm{Na}-2 \times 162-146]^{+}, 324$ [2glc] $^{+}, 309.4$ [glc-rha] $^{+}$; HRESI-MS: $m / z 967.4562[\mathrm{M}+\mathrm{Na}]^{+}$(calcd. for $\mathrm{C}_{48} \mathrm{H}_{80} \mathrm{O}_{18} \mathrm{Na}, 967.4566$ ).

22 $\alpha$-Acetyl-16 $\alpha$-hydroxyolean-12-en-28-al

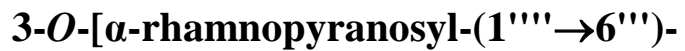

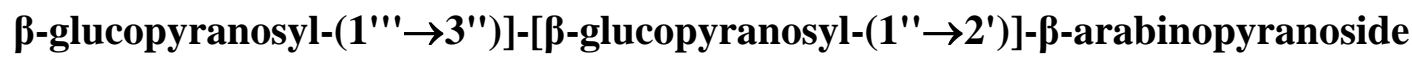
Amorphous colorless powder; $\mathrm{mp}>250{ }^{\circ} \mathrm{C} ;[\alpha]_{\mathrm{D}}{ }^{25}-49^{0}(\mathrm{MeOH}, \mathrm{c} 0.05)$; IR $v_{\max }(\mathrm{KBr}): 3450(\mathrm{OH})$, 2927, 2850, 1736 (ester group), 1711 (CHO group), 1650 (C=C), 1070, 1010 (C-O), 972, $886 \mathrm{~cm}^{-1}$; ${ }^{1} \mathrm{H}$ NMR (500 MHz, DMSO-d 6 ) $\delta$ ppm: data see Table $1 ;{ }^{13} \mathrm{C}$ NMR (125 MHz, DMSO-d 6 ) $\delta$ ppm: data see Table 2; EI-Ms (70 eV): $m / z$ (\%) 514.2 (5), 472 (4), 454 [aglycone- $\left.\mathrm{CH}_{3} \mathrm{CO}_{2} \mathrm{H}\right]^{+}(14), 436$ [aglycone- $\left.\mathrm{CH}_{3} \mathrm{CO}_{2} \mathrm{H}-\mathrm{H}_{2} \mathrm{O}\right]^{+}(25), \quad 408 \quad$ [aglycone- $\left.\mathrm{CH}_{3} \mathrm{CO}_{2} \mathrm{H}_{-}-\mathrm{H}_{2} \mathrm{O}-\mathrm{CO}\right]^{+}(10), \quad 407$ [aglycone- $\left.\mathrm{CH}_{3} \mathrm{CO}_{2} \mathrm{H}-\mathrm{H}_{2} \mathrm{O}-\mathrm{HCO}\right]^{+}(18), 389$ (6), $264\left[\mathrm{C}_{16} \mathrm{H}_{24} \mathrm{O}_{3}\right]^{+}$(100), 246 (13), 228 (14), 208 (33), 189 (10); ESI-MS: m/z 139.3544 [M+Na $]^{+} ; 1117.4[\mathrm{M}+\mathrm{H}]^{+}, 971.1[\mathrm{M}+\mathrm{H}-146]^{+}, 809.5$ $\begin{array}{lllll}{[\mathrm{M}+\mathrm{H}-162-146]} & + & 647.0 & {[\mathrm{M}+\mathrm{H}-2 \times 162-146]} & +\end{array}$ ${\text { [arabinopyranosyl-glucopyranosyl-glucopyranosyl-rhamnpyranosyl] }{ }^{+},}^{+} \quad 515.2$ $[\mathrm{M}+\mathrm{H}-2 \mathrm{x} 162-146-132]^{+}, \quad 458.3 \quad$ [arabinopyranosyl-glucopyranosyl-glucopyranosyl $]^{+}, \quad 455.3$ $\left[\mathrm{M}+\mathrm{H}-2 \mathrm{x} 162-146-132-\mathrm{CH}_{3} \mathrm{COOH}\right]^{+}, \quad 441.1$ [arabinopyranosyl-glucopyranosyl-rhamnopyranosyl] ${ }^{+}, 309.1$ [glucopyranosyl-rhamnopyranosyl] ${ }^{+}, 295.0$ [arabinopyranosyl-glucopyranosyl] ${ }^{+}$; HRESI-MS: $m / z, 1117.3425$ (calcd. for $\mathrm{C}_{55} \mathrm{H}_{88} \mathrm{O}_{23} \mathrm{H}$, 1117.3433).

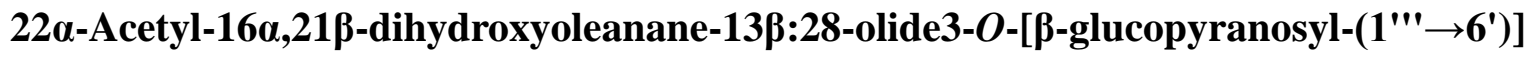
$\left[6^{\prime \prime}-O\right.$-coumaroylglucopyranosyl-(1" $\left.\left.\rightarrow 2^{\prime}\right)\right]-\beta$-glucopyranoside (5). Colorless amorphous 
powder; mp>250 ${ }^{0} \mathrm{C} ;[\alpha]_{\mathrm{D}}^{25}-89^{0}(\mathrm{MeOH}$, c 0.05$)$; IR $v_{\max }(\mathrm{KBr}): 3430(\mathrm{OH}), 2924,2853,1758$ (C=O lactone), 1737 (ester), 1655 , 1460, 1376, 1074, 1010, $875 \mathrm{~cm}^{-1}$; ${ }^{1} \mathrm{H}$ NMR (500 MHz, DMSO-d 6 ) $\delta$ ppm: data see Table $1 ;{ }^{13} \mathrm{C}$ NMR $\left(\right.$ DMSO-d $\left._{6}\right) \delta$ ppm: data see Table 3; EI-MS (70 eV): $\mathrm{m} / \mathrm{z}(\%) 546$ [aglycone] ${ }^{+}$(3), 486 [aglycone- $\left.\mathrm{H}_{2} \mathrm{O}\right]^{+}(13), 468$ [aglycone- $\left.\mathrm{CH}_{3} \mathrm{COOH}_{-} \mathrm{H}_{2} \mathrm{O}\right]^{+}(8)$, 444 (2), 426 (6), 451 (12), 382 (7), 207 (50), 198 (100); ESI-MS: m/z 1179.5 [M+H] ; 1201.4 $[\mathrm{M}+\mathrm{Na}]^{+}, 1055.1[\mathrm{M}+\mathrm{Na}-146]^{+}, 893.2[\mathrm{M}+\mathrm{Na}-162-146]^{+}, 731.3[\mathrm{M}+\mathrm{Na}-2 \mathrm{x} 162-146]^{+}, 569.0$ $[\mathrm{M}+\mathrm{Na}-2 \mathrm{x} 162-146] \quad+, 485 \quad$ [glucospyranoyl-glucopyranosyl-glucopyranosyl] ${ }^{+}, \quad 324$

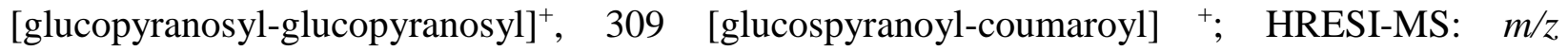
1201.5483 (calcd. for $\mathrm{C}_{59} \mathrm{H}_{86} \mathrm{O}_{24} \mathrm{Na}, 1201.5433$ ); 1179. $4527[\mathrm{M}+\mathrm{H}]+$ (calcd. For $\mathrm{C}_{59} \mathrm{H}_{86} \mathrm{O}_{24} \mathrm{H}$, 1179.4496).

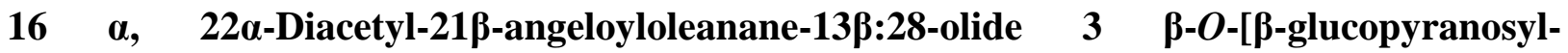
$\left.\left(1^{\prime \prime} \rightarrow 2^{\prime}\right)\right]\left[\beta\right.$-glucopyranosyl-(1"' $\left.\left.\rightarrow 4^{\prime}\right)\right]$ - $\beta$-glucopyranoside (6). Colorless amorphous powder; $\mathrm{mp}>250^{0} \mathrm{C} ;[\alpha]_{\mathrm{D}}^{25}-19^{0}(\mathrm{MeOH}, \mathrm{c} 0.05)$; IR $v_{\max }(\mathrm{KBr}): 3460(\mathrm{OH}), 2930,2855,1752(\mathrm{C}=\mathrm{O}$ lactone), 1740 (ester), $1580,1460,1380,1060,1030 \mathrm{~cm}^{-1}$; ${ }^{1} \mathrm{H}$ NMR (500 MHz, DMSO-d 6 ) $\delta$ ppm: data see Table $2 ;{ }^{13} \mathrm{C}$ NMR (DMSO-d 6 ) $\delta$ ppm: data see Table 3; ESI-MS $m / z$ 1179.4 $[\mathrm{M}+\mathrm{Na}]^{+}$, $1015.0[\mathrm{M}+\mathrm{Na}-162]^{+}, 853.3[\mathrm{M}+\mathrm{Na}-2 \times 162]^{+}, 691.0[\mathrm{M}+\mathrm{Na}-3 \times 162]^{+}, 486[\text { glucosyl x } 3]^{+}, 323$ [glucosyl-glucosyl] ${ }^{+}$; HRESI-MS: $m / z 1179.4533$ (calcd. $\mathrm{C}_{57} \mathrm{H}_{88} \mathrm{O}_{24} \mathrm{Na}, 1179.4464$ ).

$16 \alpha, 22 \alpha, 28$-Trihydroxy-21 $\beta$-angeloyloleanan-12-ene $3 \quad \beta$ - $O$-[ $\alpha$-rhamnopyranosyl$\left.\left(1^{\prime \prime \prime} \rightarrow 6^{\prime \prime}\right)\right]\left[\boldsymbol{\beta}\right.$-glucopyranosyl-(1" $\left.\left.\rightarrow \mathbf{2}^{\prime}\right)\right]-\beta$-xylopyranoside (7). Colorless amorphous powder; $\mathrm{mp}>250{ }^{0} \mathrm{C} ;[\alpha]_{\mathrm{D}}{ }^{25}-49^{0}$ (c 0.25, MeOH); IR $v_{\max }(\mathrm{KBr}): 3430-3250(\mathrm{OH}), 2920,2855,1722$ (carboxylic group), 1644 (C=C), 1460, 1385, 1360, 1250, 1180, 1041, 1015, 980, $880 \mathrm{~cm}^{-1} ;{ }^{1} \mathrm{H}$ NMR $\left(500 \mathrm{MHz}, \mathrm{CDCl}_{3}+\right.$ drop DMSO-d 6 ) $\delta \mathrm{ppm}$ : data see Table $2 ;{ }^{13} \mathrm{C} \mathrm{NMR} \mathrm{(125} \mathrm{MHz}$,

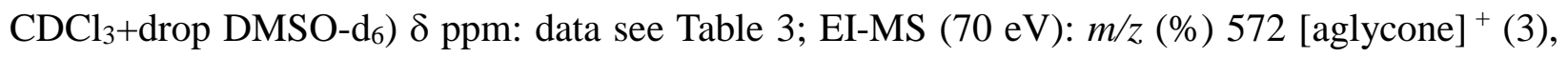
554 [aglycone- $\left.\mathrm{H}_{2} \mathrm{O}\right]^{+}(15), 536$ [aglycone- $\left.2 \mathrm{H}_{2} \mathrm{O}\right]^{+}(3), 505$ [aglycone- $\left.\mathrm{CH}_{2} \mathrm{OH}-2 \mathrm{H}_{2} \mathrm{O}\right]^{+}(8), 250$ $\left[\mathrm{C}_{16} \mathrm{H}_{26} \mathrm{O}_{2}\right]^{+}(13), 219\left[\mathrm{C}_{15} \mathrm{H}_{23} \mathrm{O}\right]^{+}(16), 207\left[\mathrm{C}_{14} \mathrm{H}_{23} \mathrm{O}\right]^{+}[27], 201\left[\mathrm{C}_{14} \mathrm{H}_{21}\right]^{+}(14], 189\left[\mathrm{C}_{14} \mathrm{H}_{21}\right]^{+}$ (100) ; ESIMS: $m / z$ 1013.3 $[\mathrm{M}+\mathrm{H}]^{+}$; $1035.2[\mathrm{M}+\mathrm{Na}]^{+}$, HRESIMS: $m / z$ 1035.3921 (calcd. $\left.\mathrm{C}_{52} \mathrm{H}_{84} \mathrm{O}_{19}, 1035.3717\right)$.

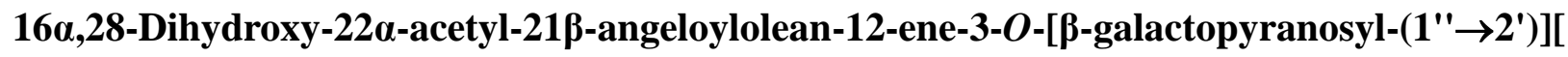
$\alpha$-rhamnopyranosyl-(1"' $\rightarrow \mathbf{4}$ ')]- $\alpha$-arabinopyranoside $(8)$. Colorless amorphous powder; mp > $250^{\circ} \mathrm{c} ;[\alpha]_{\mathrm{D}}^{25}+17^{0}$ (c 0. 01, MeOH), IR $v_{\max }(\mathrm{KBr}): 3450(\mathrm{OH}), 2930,2850,1735$ (ester carbonyl), 1718 (carboxyl carbonyl), $1650(\mathrm{C}=\mathrm{C}), 1458,1045,1035,975,920 \mathrm{~cm}^{-1} ;{ }^{1} \mathrm{H}$ NMR (500MHz, $\left.\mathrm{CDCl}_{3}+\mathrm{DMSO}_{6}\right) \delta \mathrm{ppm}$ : data see Table $2 ;{ }^{13} \mathrm{C} \mathrm{NMR}\left(125 \mathrm{MHz}, \mathrm{CDCl}_{3}+\mathrm{DMSO}-\mathrm{d}_{6}\right) \delta \mathrm{ppm}$ : data

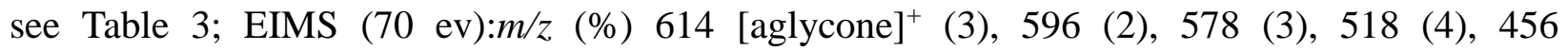
$\left[\mathrm{M}-\text { glc- } \mathrm{H}_{2} \mathrm{O}\right]^{+}(15)$; ESIMS: $m / z$ 1077.4 [M+Na $]^{+} ; 1055.4[\mathrm{M}+\mathrm{H}]^{+}$; HRESI-MS: $m / z$ 1077.4532 (calcd. $\mathrm{C}_{54} \mathrm{H}_{86} \mathrm{O}_{20} \mathrm{Na}, 1077.4485$ ).

\section{Antibacterial activity}

Test microorganisms. Eight bacteria, all clinically isolated microorganisms were obtained from New Nyanza General hospital in Kisumu, Kenya. The bacterial pathogens were Staphylococcus aureus, Bacillus subtilis, Streptococcus pneumoniae, Enterococcus faecalis, Salmonella typhii, 
Vibro cholera, Escherichia coli and Pseudomonas aeruginosa.

Antibacterial susceptibility test. The sensitivity testing of crude extract was done using agar well diffusion method. ${ }^{39,40}$ The bacterial isolates were first grown in nutrient broth (Oxoid) for $24 \mathrm{~h}$ before use. The inoculum suspensions were standardized and then tested against the effect of crude extract at concentration of $500 \mu \mathrm{g} / \mathrm{ml}$. The plates were incubated at $37^{\circ} \mathrm{C}$ and observed for zones of inhibition after $48 \mathrm{~h}$. The effect of the extract was compared with those of gentamycin and streptomycin at a concentration of $1 \mu \mathrm{g} / \mathrm{ml}$ each.

Minimum inhibitory concentration (MIC). Minimum inhibitory concentration (MIC) of crude extract and pure isolates was determined using broth micro-dilution technique ${ }^{41,42,43}$. Stock solution of extract was two fold diluted with RPMI 1000-1 $\mu \mathrm{g} / \mathrm{ml}$ (final volume $=100 \mu \mathrm{l}$ ) and a final DMSO concentration $\leq 1 \%$. Pure compounds were dissolved in DMSO and different concentrations ranging between 200 and $1 \mu \mathrm{g} / \mathrm{ml}$ prepared. Approximately $2 \mathrm{ml}$ of the concentrate from each dilution was added to $20 \mathrm{~mL}$ of molten agar (Oxoid Ltd) and uniformly mixed in a sterile Petri dish, then allowed to settle. A volume of $100 \mu 1$ of inoculum suspension was added to each well with exception of the sterility control where sterile water was added to the well instead. The plates were incubated at $37{ }^{0} \mathrm{C}$ for up to $48 \mathrm{~h}$. MIC was taken as the lowest concentration of extract or pure compound which resulted in total inhibition of the bacterial growth. The effects of the standard antibiotics (gentamycin and streptomycin) were taken as positive controls.

Acid hydrolysis. Compounds 1-8, 11, 12, 14, 15 and 16, each $10 \mathrm{mg}$ ), each in a mixture of 8\% $\mathrm{HCl}(1 \mathrm{~mL})$ and $\mathrm{MeOH}(5 \mathrm{~mL})$ were separately refluxed for $2 \mathrm{~h}$ at $100^{\circ} \mathrm{C}$, after which the reaction mixture cooled. After cooling, the mixture was extracted with EtOAc saturated with water. The EtOAc layer evaporated and the aglycone analyzed by NMR and MS and also data compared with the relevant literature. The water residues were reduced in vacuo to dryness, dissolved in $\mathrm{H}_{2} \mathrm{O}$ ( 1 $\mathrm{mL}$ ) and neutralized with $\mathrm{NaOH}$. The neutralized products were subjected to silica TLC analysis (eluent: EtOAc-MeOH-H${ }_{2} \mathrm{O}-\mathrm{HOAc}$, 6:2:1:1) and PC (eluents: n-BuOH-HOAc- $\mathrm{H}_{2} \mathrm{O}$, 4:5:1 and $\mathrm{C}_{6} \mathrm{H}_{6}-\mathrm{n}-\mathrm{BuOH}-\mathrm{H}_{2} \mathrm{O}$-pyridine, 1:5:3:3). The chromatograms were sprayed with aniline hydrogen phthalate followed by heating at $100{ }^{\circ} \mathrm{C}$. The sugars were identified after comparison of their $\mathrm{R}_{\mathrm{f}}$ values with authentic samples.

Further confirmation of the sugar residues was performed according to the known method 44 whereby the reaction mixture was evaporated under a stream of nitrogen. Each residue was dissolved in 1-(trimethylsilyl) imidazole and pyridine $(0.2 \mathrm{~mL})$, and the solution was stirred for 5 minutes. After drying the solution, the residue was partitioned between $\mathrm{H}_{2} \mathrm{O}$ and $\mathrm{CHCl}_{3}$. The $\mathrm{CHCl}_{3}$ layer was subjected to $\mathrm{GC}$ using a L-CP-chirasil val column $(0.32 \mathrm{~mm}$ x $25 \mathrm{~m})$. Temperatures of the injector and detector were $200^{\circ} \mathrm{C}$ for both. A temperature gradient system was used for the oven, starting at $100^{\circ} \mathrm{C}$ for $1 \mathrm{~min}$ and increasing up to $180^{\circ} \mathrm{C}$ at a rate of $5^{\circ} \mathrm{C} / \mathrm{min}$. Peaks of the hydrolysates were detected by comparison with retention times of authentic samples after treatment with 1-(trimethylsilyl)imidazole in pyridine. 


\section{Acknowledgements.}

The authors are thankful to Kenya Medical Research Institute (KEMRI), Kisumu, Kenya for the use of their laboratory to perform the biological activity tests. Mr. Mathenge of Botany Department, Nairobi University is highly thanked for identification of the plant. Dr. Serem of Maseno University clinic is acknowledged for the identification of the bacteria.

\section{References and Notes}

1. Kokwaro, J. A. Medicinal Plants of East Africa; East African Literature Bureau. Nairobi, 1976.

2. Midiwo, J. O.; Manguro, L. O. A.; Mbakaya, C. L. Bull. Chem. Soc. Ethiop. 1988, 3, 83.

3. Midiwo, J. O.; Odingo, J. O.; Manguro, L O. A. Bull. Chem. Soc. Ethiop. 1990, 4, 71.

4. Midiwo, J. O.; Manguro, L. O. A. Intern. J. Biochemiphysics 1993, 2, 115.

5. Manguro, L. O. A.; Midiwo, J. O.; Kraus, W.; Ugi, I. Phytochemistry 2003, 64 (4), 855.

6. Apers, S.; De Bruyne, T. E.; Claeys, M.; Vlietlinck, A. J.; Pieters, L. A. C. Phytochemistry 1999, 52, 1121.

7. Sindambiwe, J. B.; Balde, A. L.; De Bruyne, T. E.; Pieters, L.; Van den Heuvel, H.; Claeys, M.; Van den Berghe, D. A.; Vlietlinck, A. Phytochemistry 1996, 41 (1), 269.

8. Apers, S.; Foriers, A.; Sindambiwe, J. B.; Vlietlinck, A.; Pieters, L. J. Pharmaceut. Biomed. Anal. 1998, 18, 737.

9. Manguro, L. O. A.; Ugi, I.; Lemmen, P. Nat. Prod. Sci. 2003, 1, 54.

10. Ohtani, K.; Mavi, S.; Hostettman, K. Phytochemistry 1993, 33, 83.

11. Bittner, S.; Grinberg, S.; Kiprono, P. C.; Machocho, A. K. Phytochemistry 2003, 62, 573.

12. De Napoli, L.; Piccialli, G.; Picialli, V.; Santacroce, C.; Carolla, R. Phytochemistry 1992, 31, 3965.

13. Manguro, L. O. A.; Okwiri, S. O.; Lemmen, P. Phytochemistry 2006, 67, 2641.

14. Mahato, S. B.; Kundu, A. P. Phytochemistry 1994, 37, 1517.

15. Kiem, P. V.; Thu, V. K.; Yen, P. H.; Tung, N. H.; Guong, N. X.; Minh, C. V.; Huong, H. T.; Hyun, J. H.; Kang, H. K.; Kim, Y. H. Chem. Pharm. Bull (Tokyo) 2009, 57, 102

16. Jia, Z.; Koike, K.; Nikaido, T.; Ohmoto, T.; Ni, M. Chem. Pharm. Bull. 1994, 42, 2309.

17. Mohmoud, I. I.; Marzouk. M. S. A.; Moharram, F. A.; El-Gindi, M. R.; Hassan, A. M. K. Phytochemistry 2001, 56 (8), 1239.

18. Chang, X.; Li, W.; Jia, Z.; Satou, T.; Fushiza, S.; Koike, K. J. Nat. Prod. 2007, 70, 179.

19. Alliota, G.; De Napoli, L.; Giordano, F.; Piciaali, G..; Picialli, V.; Santacroce, C. Phytochemistry 1992, 31, 929.

20. Guo, S.; Kenne, L. Phytochemistry 2000, 55, 419.

21. Cimanga, K.; de Bruyne, T.; Van Poel, B.; Ma, Y.; Claeys, M.; Pieters, L.; Kabangu, K.; Tona, L.; Bakana, P.; Vanden Berghe, D.; Vlietnick, A. Planta Med. 1997, 62, 220. 
22. Yang, Y.; Chen, Q.; Hu, L. Phytochemistry 2007, 68, 1752.

23. Tang, Y.; Lou, F.; Wang, J.; Li, Y., Zhuang, S. Phytochemistry 2001, 58, 1251.

24. Hui, W.; Li, M. Phytochemistry 1976, 15, 1741.Kitagawa, I.; Kitawaza, K.; Yosioka, I. Tetrahedron 1972, 28, 907.Majumber, P. L.; Bagchi, A. Tetrahedron 1983, 39, 649.Kalinovskii, A. I. Chemistry of Natural Compounds 1992, 28:1.Huang, H. C.; Liaw, C. C.; Zhang, L. J.; HO, H. O.; Yang Kuo, L. M.; Shen, Y. C.; Kuo, Y. H. Phytochemistry 2008, 69, 1597.Curir, P.; Dolci, M.; Lanzotti, V.; Taglialatela-Scafi, O. Phytochemistry 2001, 56, 717.Zhang, Z.; Li, S.; Zhang, S.; Gorenstein, D. Phytochemistry 2006, 67, 784. Yoshikawa, M.; Murakami, T.; Matsuda, H.; Yamahara, J., Murakami, N.; Kitagawa, I. Chem. Pharm. Bull. 1996, 44, 1554.Yoshikawa, M.; Murakami, T.; Yamahara, J.; Matsuda, H. Chem. Pharm. Bull. 1998, 46, 1764.Zhang, Z. Z.; Koike, K.; Jia, Z. H.; Nikaido, T.; Guo, D. A.; Zheng, J. H. Chem. Pharm. Bull. 1999, 47, 1515-1520.Konoshima, T.; Lee, K. H. J. Nat. Prod. 1986, 49, 650.Pal, B. C.; Chaudhri, T.; Yoshikawa, K.; Arihara, S. Phytochemistry 1994, 35, 1315.Jia, Z.; Koike, K.; Nikaido, T. J. Nat. Prod. 1998, 61, 1368.Paphassarang, S.; Raynaud, J.; Lussignol, M.; Becchi, M. Phytochemistry 1989, 28, 1539.Maes, L.; Vanden Berghe, D.; Germonprez, N Quirijnen, L.; Paul Cos, L; De Kimpe, N.; Van Puyvelde L. Antimicrobial Agents and Chemother. 2004, 48, 130.

39. Irobi, O. N.; Moo-Young, M.; Anderson, W. A.; Daramola, S. O. Intern, J, Pharmacog. 1994, $34,87$.

40. Clark, A. M.; El-Feraly, F.; Li, W. S. J. Pharm. Sci. 1981; 70: 951.

41. Taniguchi, M.; Chapya, A.; Kubo, I., Nakanishi, K. Chem. Pharm. Bull. 1978, 26, 2910.

42. Liu, S.; Oguntimein, B.; Hufford, C. D.; Clark, A. M. Antimicrobial Agents Chemother. 1990, $34,529$.

43. Hammerschmidt, F. J.; Clark, A. M.; Soliman, F. M.; El-Kashoury, E. A.; Abd El-Kawy, M. M.; El-Fishawy, A. M. Planta Med. 1993, 59, 68.

44. De Leo, M.; De Tommasi, N.; Sanogo, R.; D’Angelo, V.; Germanò, M. P.; Bisignano, G.; Braca, A. Phytochemistry 2006, 67, 2623. 